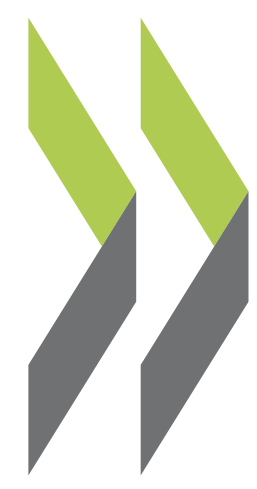

OECD Economics Department Working Papers No. 1394 Jon Pareliussen,

Income, wealth and equal Christophe André, opportunities in Sweden Hugo Bourrousse, Vincent Koen 
Organisation de Coopération et de Développement Économiques

Organisation for Economic Co-operation and Development

20-Jun-2017

ECONOMICS DEPARTMENT

English - Or. English

\section{INCOME, WEALTH AND EQUAL OPPORTUNITIES IN SWEDEN}

ECONOMICS DEPARTMENT WORKING PAPERS No. 1394

By Jon Pareliussen, Christophe André, Hugo Bourrousse and Vincent Koen

OECD Working Papers should not be reported as representing the official views of the OECD or of its member countries. The opinions expressed and arguments employed are those of the author(s).

Authorised for publication by Alvaro Pereira, Director, Country Studies Branch, Economics Department.

All Economics Department Working Papers are available at www.oecd.org/eco/workingpapers

Complete document available on OLIS in its original format

This document, as well as any data and map included herein, are without prejudice to the status of or sovereignty over any territory, to the delimitation of international frontiers and boundaries and to the name of any territory, city or area. 
OECD Working Papers should not be reported as representing the official views of the OECD or of its member countries. The opinions expressed and arguments employed are those of the author(s).

Working Papers describe preliminary results or research in progress by the author(s) and are published to stimulate discussion on a broad range of issues on which the OECD works.

Comments on Working Papers are welcomed, and may be sent to OECD Economics Department, 2 Rue André-Pascal, 75775 Paris Cedex 16, France, or by e-mail to eco.contact@oecd.org.

All Economics Department Working Papers are available at www.oecd.org/eco/workingpapers.

This document and any map included herein are without prejudice to the status of or sovereignty over any territory, to the delimitation of international frontiers and boundaries and to the name of any territory, city or area.

The statistical data for Israel are supplied by and under the responsibility of the relevant Israeli authorities. The use of such data by the OECD is without prejudice to the status of the Golan Heights, East Jerusalem and Israeli settlements in the West Bank under the terms of international law.

Latvia was not an OECD Member at the time of preparation of this publication. Accordingly, Latvia does not appear in the list of OECD Members and is not included in the zone aggregates.

\section{(C) OECD (2017)}

You can copy, download or print OECD content for your own use, and you can include excerpts from OECD publications, databases and multimedia products in your own documents, presentations, blogs, websites and teaching materials, provided that suitable acknowledgment of OECD as source and copyright owner is given. All requests for commercial use and translation rights should be submitted to rights@oecd.org 
ECO/WKP(2017)26

\section{ABSTRACT/RESUME}

\section{Income, wealth and equal opportunities in Sweden}

Sweden is an egalitarian society in international comparison, and has managed to combine equity with economic efficiency. Rapidly rising inequality and relative poverty from a historical low in the 1980s partly stem from ageing, changing family structures and migration. Living standards increased for all groups, but social benefits rose less than earned income. Incomes of newly-arrived immigrants and single mothers trailed the median. Bottlenecks in the migrant settlement process are costly to migrants and society, and high entry wages further slow integration. Spatial segregation leads to school segregation and potentially reduced social mobility for the least endowed, and rental regulations reduce the scope for settling where job opportunities are the best. Fast-growing capital incomes, likely linked to increasing wealth concentration and income shifting, increased inequality. Low intergenerational income mobility in the very top of the income distribution is a concern. Social benefits should be uprated more systematically and regressive housing-related taxation reformed to strengthen redistribution. Migrant settlement and integration need to be better coordinated and adapted to individual starting points. The number of wage subsidies and their administrative complexity should be reduced to ease labour market entry. Dysfunctional rental regulations should be reformed to increase mobility and limit spatial segregation.

This working paper relates to the 2017 OECD Economic Survey of Sweden (www.oecd.org/eco/surveys/economic-survey-sweden.htm).

\section{JEL: D31, F22, H23 H55}

Keywords: Income, wealth, inequality, redistribution, migration, skills, housing, rent control.

$* * * * * * * * * * * * * *$

\section{Revenus, richesses et égalité des chances en Suède}

La Suède est une société égalitaire en comparaison internationale et a réussi à combiner l'équité et l'efficacité économique. La croissance rapide des inégalités et de la pauvreté relative à partir d'un niveau historiquement bas dans les années 1980 résulte en partie du vieillissement, de l'évolution des structures familiales et des migrations. Le niveau de vie a augmenté pour toutes les catégories de la population, mais les prestations sociales ont crû plus faiblement que les revenus d'activité. Les revenus des immigrants nouvellement arrivés et des mères célibataires ont augmenté plus lentement que le revenu médian. Les goulots d'étranglement dans le processus d'installation des migrants sont coûteux pour les migrants et la société, et les salaires d'entrée élevés ralentissent encore l'intégration. La ségrégation spatiale conduit à la ségrégation scolaire et à une mobilité sociale potentiellement réduite pour les moins favorisés, et la règlementation du marché du logement locatif réduit les possibilités de mobilité vers les lieux offrant les meilleures opportunités d'emploi. La forte croissance des revenus du capital, probablement liée à l'augmentation de la concentration de la richesse et à des reclassifications de revenus, a augmenté les inégalités. La faible mobilité intergénérationnelle au sommet de la répartition des revenus est préoccupante. Les prestations sociales devraient être revalorisées de manière plus systématique et la fiscalité régressive liée au logement réformée pour renforcer la redistribution. L'installation et l'intégration des migrants devraient être mieux coordonnées et adaptées aux conditions individuelles. Le nombre de subventions salariales et leur complexité administrative devraient être réduits pour faciliter l'entrée sur le marché du travail. La règlementation inadaptée du marché du logement locatif devrait être réformée pour accroître la mobilité et limiter la ségrégation spatiale.

Ce Document de travail se rapporte à l'Étude économique de l'OCDE de la Suède 2017 (www.oecd.org/fr/eco/etudes/etude-economique-suede.htm).

JEL: D31, F22, H23 H55

Mots clés : Revenu, richesse, inégalité, redistribution, migration, compétences, logement, contrôle des loyers 


\section{TABLE OF CONTENTS}

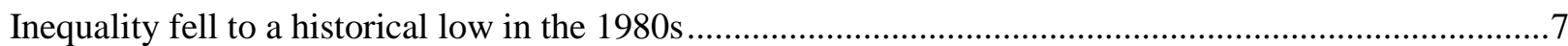

Living standards rose for all income groups, but more slowly at the bottom than at the top.................9

The reforms of the late 1990s increased inequality, but brought about sustained economic growth......12

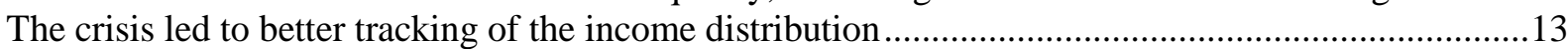

The uprating system led to a gradual erosion of working-age benefits .................................................13

The rise in inequality was partly due to demographic and other structural trends ................................14

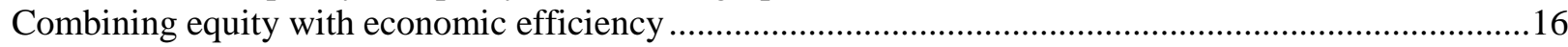

Wage compression, redistribution and growth ..................................................................................

Absorbing the increasing supply of low-skilled workers is challenging ..............................................19

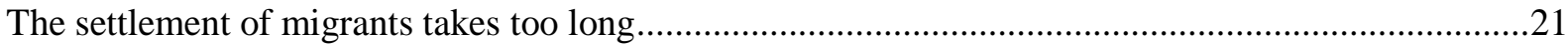

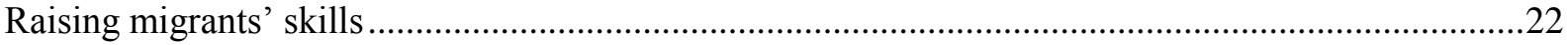

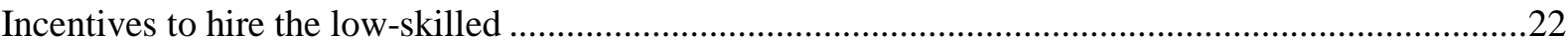

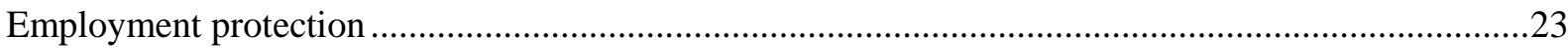

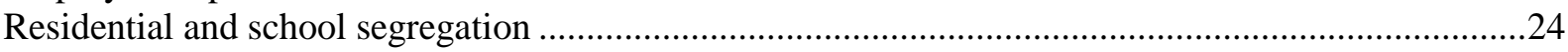

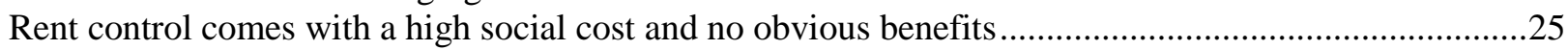

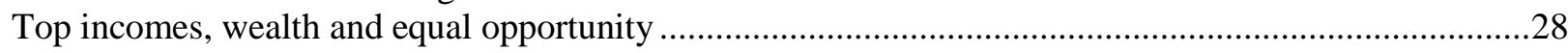

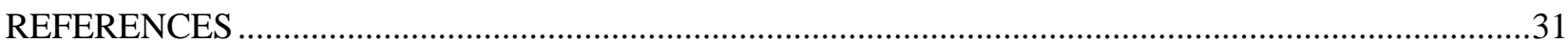

\section{Tables}

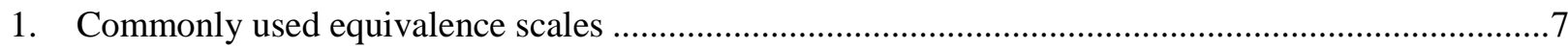

2. Structural contributions to increasing inequality ......................................................................... 16

\section{Figures}

1. Inequalities have been widening since the 1990s, but remain low .....................................................6

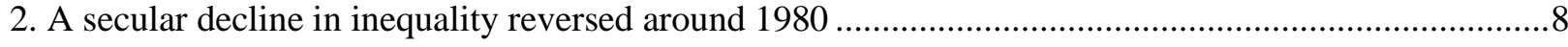

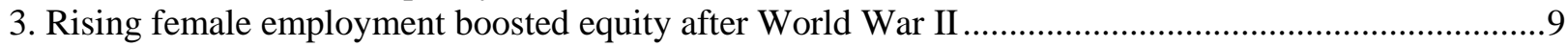

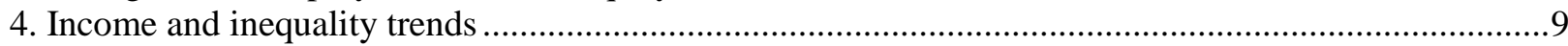

5. The income distribution has widened since the 1990s ....................................................................

6. Relative incomes fell while purchasing power increased in the lower part of the distribution .............11

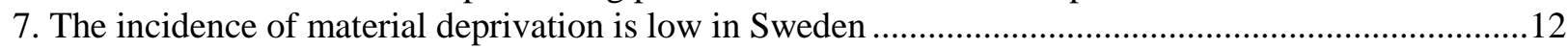

8. Structural change increased inequalities ...................................................................................... 14

9. The evolution of the shares of productive spending and distortionary taxation .................................17

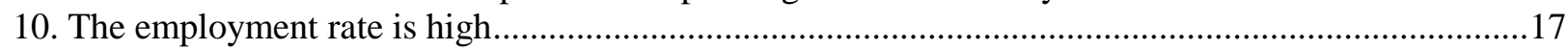

11. Countries with low gross earnings inequality also tend to have higher social spending ....................18

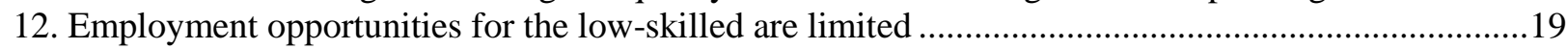

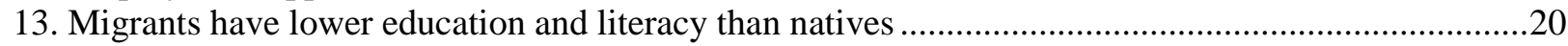

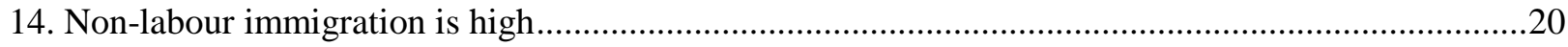

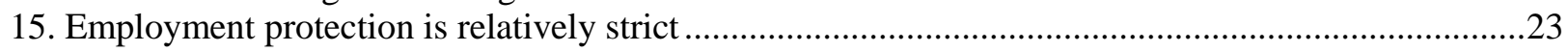

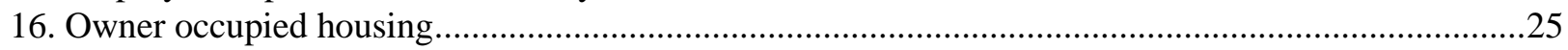

17. Overcrowding is fairly common in the bottom $20 \%$ of the income distribution ................................26

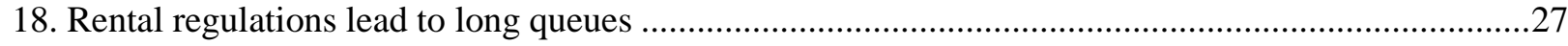




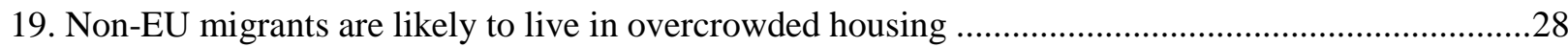

20. Rising top incomes contributed strongly to widening inequality....................................................29

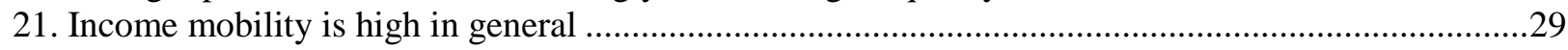

\section{Boxes}

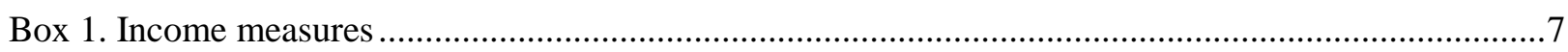

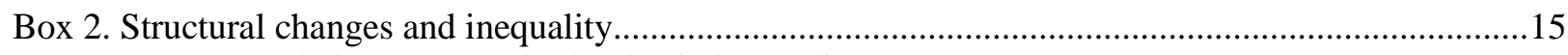

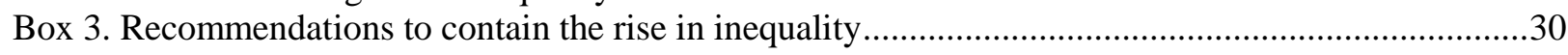




\title{
INCOME, WEALTH AND EQUAL OPPORTUNITIES IN SWEDEN
}

\author{
By Jon Kristian Pareliussen, Christophe André, Hugo Bourrousse, Vincent Koen ${ }^{1}$
}

Income inequality in Sweden fell to historical lows in the 1980s but has since increased. Social benefits rose less than earned income growth, and fast-growing capital gains and dividends boosted top incomes. Today, Sweden is still one of the most egalitarian OECD countries, but the Gini coefficient of household disposable income has increased more in Sweden than in any other OECD country with available data, and is now the highest among the Nordics (Figure 1). Furthermore, following record-high, mostly humanitarian and family reunion immigration, 16\% of the population was foreign-born in 2015. The foreign born are less likely to be employed, and they often earn less and work in occupations with lower status than natives with similar education.

Figure 1. Inequalities have been widening since the 1990s, but remain low

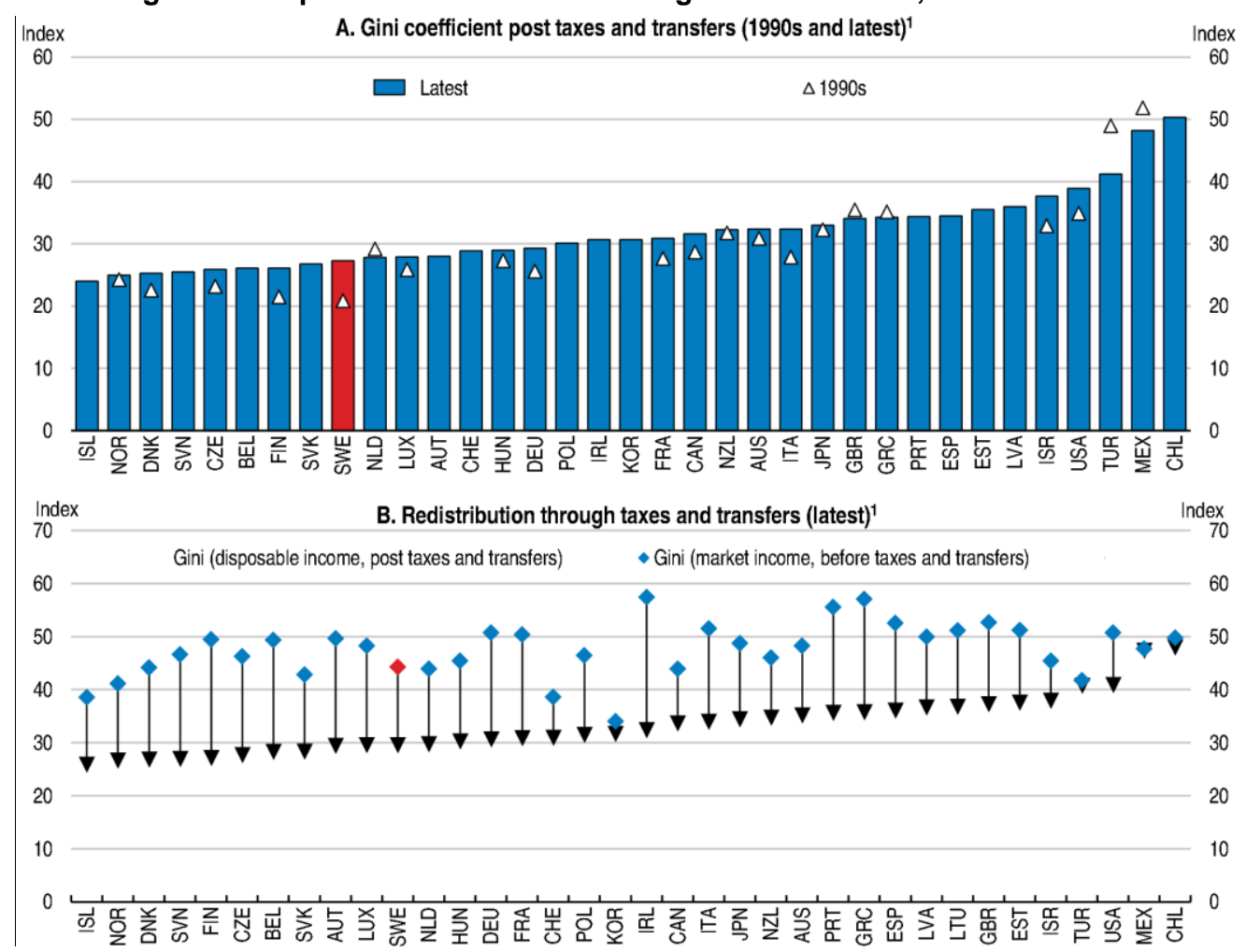

1. The Gini index measures the extent to which the distribution of income deviates from a perfectly equal distribution. A Gini index of zero represents perfect equality and 100 represents perfect inequality. "Latest" refers to 2012 except for Canada (2011), Finland, Israel, Korea, the Netherlands, the United States (2013) and Hungary (2014).

Source: OECD Income Distribution and Poverty database.

\footnotetext{
${ }^{1}$ Authors were all at the OECD Economics Department at the time of writing. The authors would like to thank warmly Swedish authorities, members of the OECD Economic Development and Review Committee, Per Olof Robling from the University of Stockholm, Robert Ford, Mikkel Hermansen, Asa Johansson, Patrick Lenain and Alvaro Pereira from the OECD Economics Department, Bert Brys and Pierce O'Reilly from the OECD Centre for Tax Policy and Administration, Willem Adema, Michael Förster, Monica Queisser and Angelica Salvi Del Pero from the OECD directorate for Employment, Labour and Social Affairs for invaluable comments and suggestions. Mercedes Burgos and Sisse Nielsen (also from the OECD Economics Department) provided excellent secretarial support.
} 


\section{Box 1. Income measures}

Income inequality is often derived from equivalised disposable income. This measure takes into account market (factor) income, taxes, transfers and economies of scale in household consumption.

Market (factor) income: The starting point for all income measures is individual market income, which consists of wages, salaries and income from self-employment, as well as capital and property income.

Household income: Even though individual incomes are relevant, notably in the study of gender equality, they fail to adequately capture differences in living standards. To evaluate income inequality it is therefore common to pool the market incomes of all the members of a household to arrive at household market income.

Disposable income: Disposable income is obtained by adding transfers and subtracting direct taxes from market income, usually at the household level. Disposable income can also be adjusted by adding the consumption of public services, but this is seldom done because such data are not readily available.

Equivalised income: Household income can be reported on a per capita basis. However, the needs of a household do not grow proportionally to the number of household members because of economies of scale in household consumption. The needs for housing space and electricity will for example not be three times as high for a household with three members than for a single person. It is therefore common to assign household income to members of the household using an equivalence scale. There is no internationally recognised standard equivalence scale, but some of the most commonly used scales include the "(old) OECD equivalence scale", which assigns a value of 1 to the first household member, 0.7 to each additional adult and 0.5 to each child; the "OECD-modified scale", which assigns a value of 1 to the household head, 0.5 to each additional adult member and 0.3 to each child; and the square root scale, which is the square root of the number of family members. Statistics Sweden uses an equivalence scale which assigns a value of 1 to the first adult, 0.51 to the second and 0.60 to subsequent adults, 0.52 to the first, and 0.42 to subsequent children (Table 1). Equivalised income is derived by dividing pooled household (disposable or market) income by the relevant number from the equivalence scale.

Table 1. Commonly used equivalence scales

\begin{tabular}{lccccc}
\hline \multicolumn{1}{c}{ Household } & Equivalence scale & \\
\hline & Per capita & $\begin{array}{c}\text { (Old) “OECD } \\
\text { scale" }\end{array}$ & $\begin{array}{c}\text { OECD-modified } \\
\text { scale }\end{array}$ & $\begin{array}{c}\text { Square root } \\
\text { scale }\end{array}$ & $\begin{array}{c}\text { Statistics } \\
\text { Sweden }\end{array}$ \\
\hline 1 adult & 1 & 1.0 & 1.0 & 1.0 & 1.0 \\
2 adults & 2 & 1.7 & 1.5 & 1.4 & 1.5 \\
2 adults, 1 child & 3 & 2.2 & 1.8 & 1.7 & 2.0 \\
2 adults, 2 children & 4 & 2.7 & 2.1 & 2.0 & 2.5 \\
1 adult, 1 child & 2 & 1.5 & 1.3 & 1.4 & 1.5 \\
\hline
\end{tabular}

Source: OECD (2013); Statistics Sweden (2016).

To shed light on the sources of income inequality in Sweden, this paper gives an overview of developments in income inequality over time, in particular after the 1980s, but some trends are traced back to the $18^{\text {th }}$ century. Income is measured as equivalised disposable income unless otherwise specified (Box 1), but other measures of income and wealth are also used. The paper seeks to explain how structural trends, such as longevity and household structure, as well as different sources of market income, taxes and transfers, have shaped the rise in inequalities over the past two decades, and how policies can be adjusted to contain the rise in inequality in a rapidly changing society.

\section{Inequality fell to a historical low in the 1980s}

A long trend of falling income inequality in Sweden turned in the 1980s (Figure 2). The falling trend pre-dates the rise of the welfare state in the 1960s and 1970s by several decades, and drivers of equity have varied over time. Several early reforms and societal trends associated with the modernisation and 
industrialisation of the country from the $18^{\text {th }}$ century onwards brought about strong economic growth combined with greater equity. Such win-win opportunities became increasingly scarce towards the end of the $20^{\text {th }}$ century. Sweden has converged towards the best policy frontier on several dimensions, which implies starker policy trade-offs between efficiency and equity (Andersen and Maibom, 2016).

\section{Figure 2. A secular decline in inequality reversed around 1980}

Top 10 percent income share ${ }^{1}$

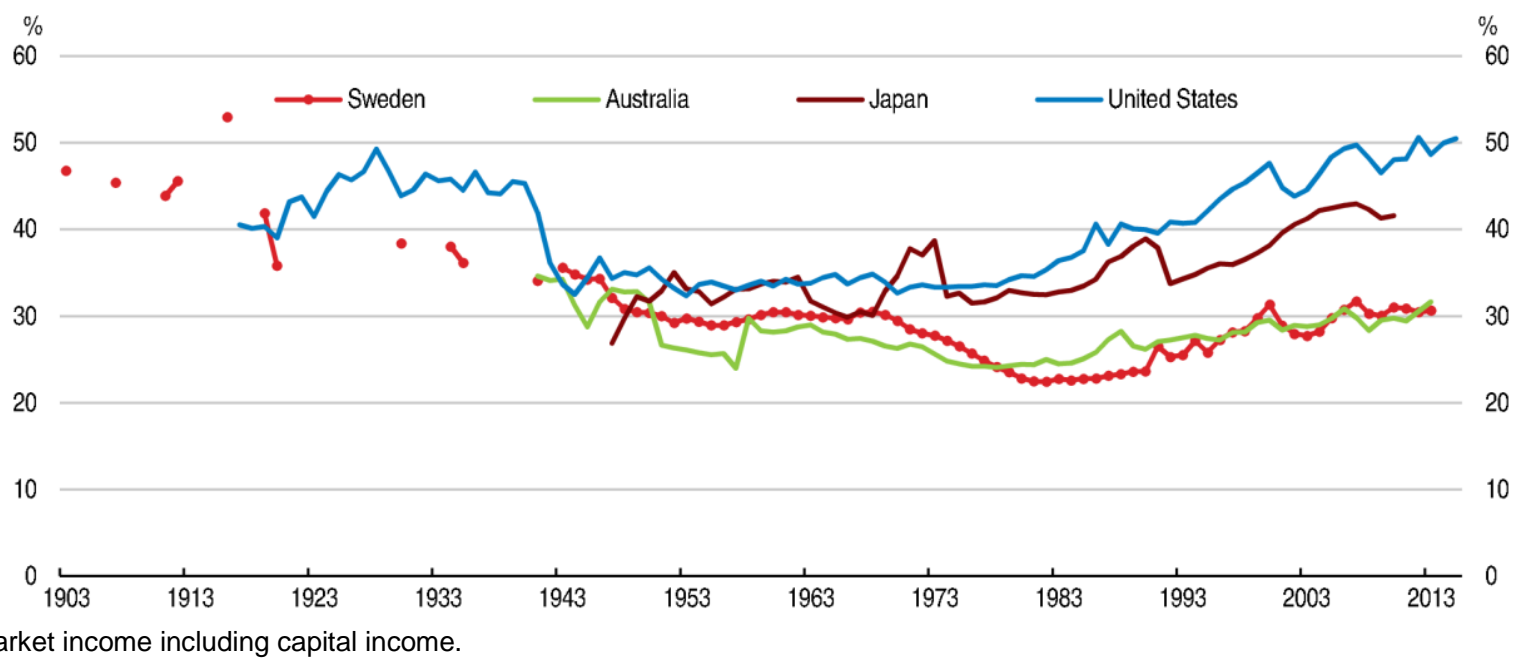

Source: The World Wealth and Income database.

Starting in the late 1700 s, land reform rearranged what was previously a patchwork of plots into organised squares around farms. The reforms also gave farmers ownership of their plots, which spurred productivity improvements to the benefit of the mostly rural population. The growth of local savings banks from the 1840s and steadily rising savings (Soltow, 1989) underpinned this trend, making for better functioning and more inclusive credit intermediation. Compulsory elementary school was introduced in 1842 , making access to education more egalitarian. Increasingly meritocratic recruitment of civil servants and the removal of aristocratic rights to high positions in 1845 coincided with the establishment of a free press and civil servants earning salaries instead of charging fees for their services. These changes opened up opportunities that were earlier reserved for the aristocracy and the well connected. Furthermore, they increased the accountability and efficiency of the public sector, facilitating the emergence of Swedish industry, which was also boosted by increased freedom of movement of goods, labour and capital. The expansion of manufacturing jobs increased the productivity of labour migrating from the countryside, although part of the surplus workforce emigrated, notably to the United States. The growing membership of trade unions from the end of the $19^{\text {th }}$ century and their cooperation with employer unions, further school reforms increasing the quantity and quality of compulsory education, progressive taxation of income (1903) and wealth (1911) and early social insurance schemes from the late $19^{\text {th }}$ century lifted equity further in the first half of the $20^{\text {th }}$ century (Bergh, 2011).

Inequalities continued to fall steeply after the Second World War. Many of the early reforms mentioned above continued to have an effect, and the welfare state expanded progressively. The 1940 school reform and the introduction of universal sickness insurance in 1955 had important and lasting equalising effects (Bjorklund et al., 2009; Bergh, 2011). However, the spectacular fall of the Gini coefficient of individual market income from above 50 in 1950 to around 32 in 1985 was almost entirely driven by rising female employment (Figure 3; Johansson and Lindh, 2006). An expanding public sector gave women employment opportunities, eased labour force entry by expanding childcare, elderly care and schooling, and also increased demand for such services. Increasing female employment has, in addition to lowering inequality of individual income, been found to lower inequality of equivalised income (OECD, 2011). 
Figure 3. Rising female employment boosted equity after World War II
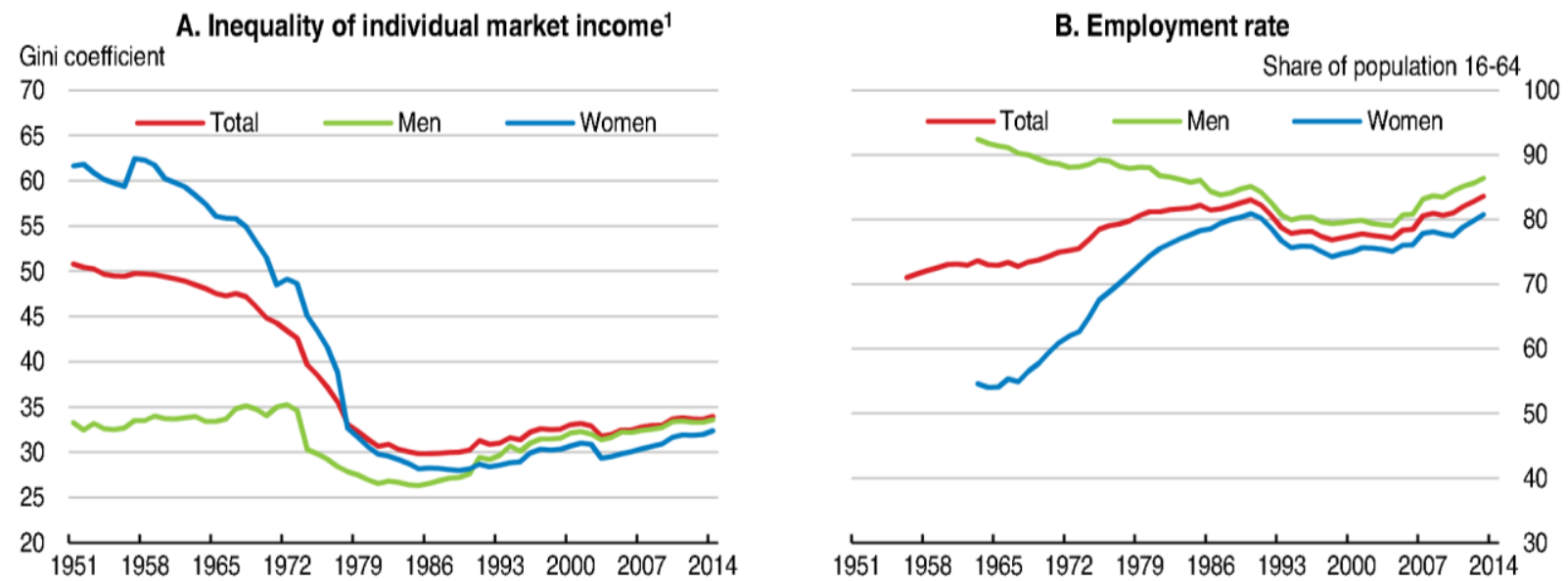

1. Gini coefficients from 1951 to 1990 are calculated on the basis of income deciles from Johansson and Lindh (2009) and spliced in 1991 with coefficients calculated from tax data in income brackets from Statistics Sweden.

Sources: Johansson and Lindh (2009), Swedish National Data Service; Statistics Sweden, Incomes and Taxes database; and OECD Annual Labour Force Statistics database.

\section{Living standards rose for all income groups, but more slowly at the bottom than at the top}

Household market income inequality rose steadily from 1975 to 1994, but has remained stable since. Disposable income inequality bottomed out in 1981, and did not rise much until the 1990s. Taxes and transfers have a strong redistributive effect in Sweden. However, this equalising effect has fallen both in absolute and percentage terms since the 1990s, as stable household market income inequality is accompanied by a continued rise in the Gini coefficient after taxes and transfers (Figure 4). Inequality has increased more in Sweden than in any other OECD country with available data, reflecting high income growth in the middle- and higher parts of the distribution. But incomes of the bottom $10 \%$ of the population have also grown somewhat more than in the OECD median country. To measure inequalities correctly, the consumption value of free or subsidised public services should in principle be included in the income measure. This reduces the level of inequality indicators considerably, and the equalising effect differs between countries. Comparable data accounting for public services are not regularly compiled, but 2007 data showed that accounting for public services did not materially change Sweden's ranking relative to other OECD countries (OECD, 2011).

Figure 4. Inequality trends before and after taxes and transfers ${ }^{1}$

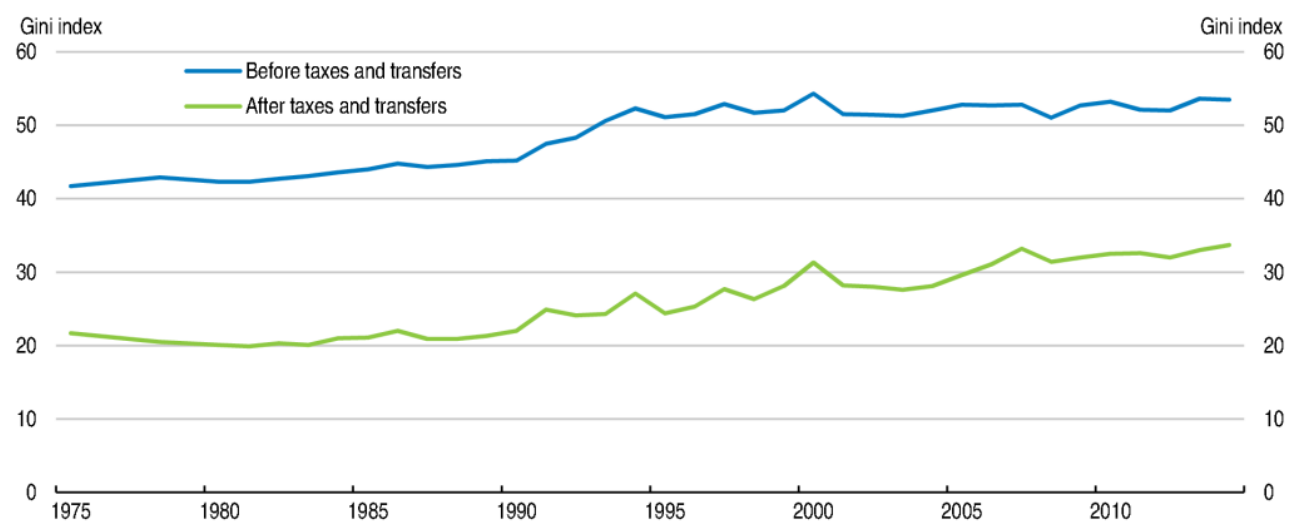

1. Equivalised income including capital income. An old definition of households is used to enable comparison over time. Inequality levels are therefore higher than in official statistics.

Sources: Statistics Sweden. 
The median real income for the total population grew by an average of $2.7 \%$ per year from 1995 to 2014 , but growth was slower at the lower end of the distribution than at the higher end, pushing up inequality (Figure 5, Panels A and B). Income growth at the high end of the distribution has largely been driven by growing capital incomes, contrary to the United States and the United Kingdom, where salaries played a greater role (Heathcote et al., 2010; Blundell and Etheridge, 2010). Weaker income growth in the lower part of the distribution is to a large extent a result of social benefits growing more slowly than wages. A majority of individuals in the three lowest income deciles have public transfers as their main source of income (Figure 5, Panel C). Those who are not in employment have therefore seen their relative living standards eroded (Figure 5, Panel D; Ministry of Finance, 2016a).

Figure 5. The income distribution has widened since the $1990 \mathrm{~s}^{1}$

A. The income distribution has widened
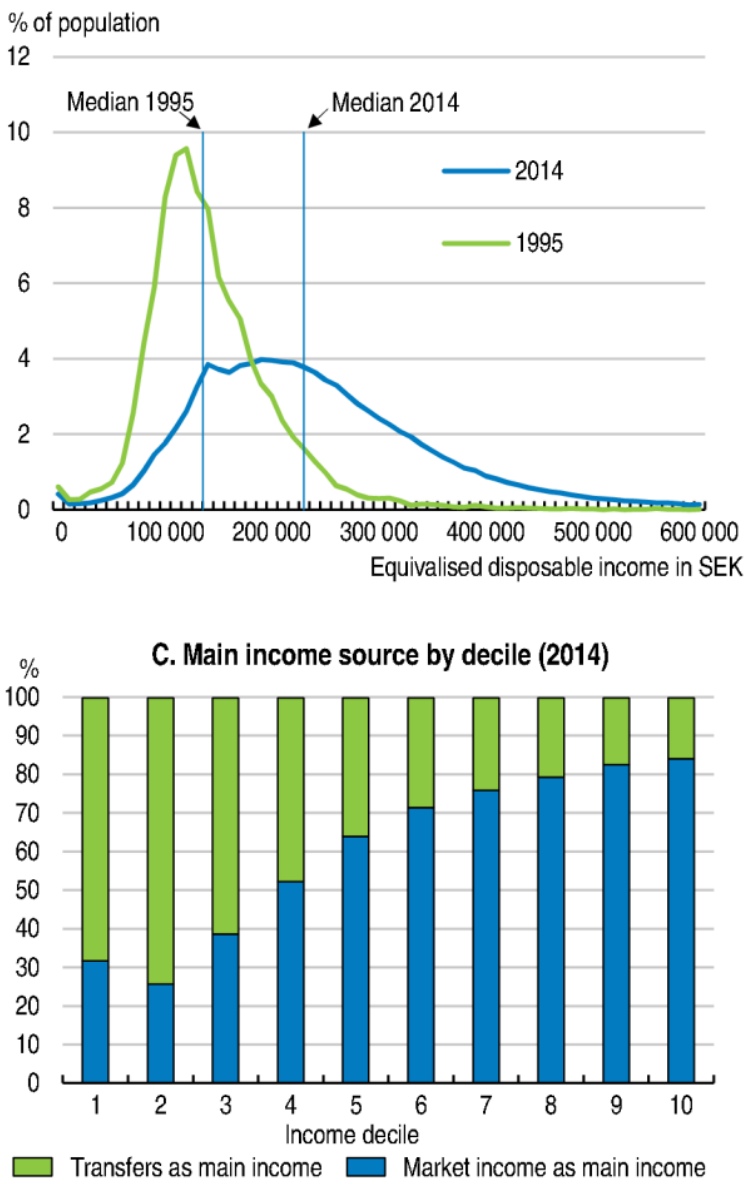

B. Top earnings and capital gains grew quickly ${ }^{2}$

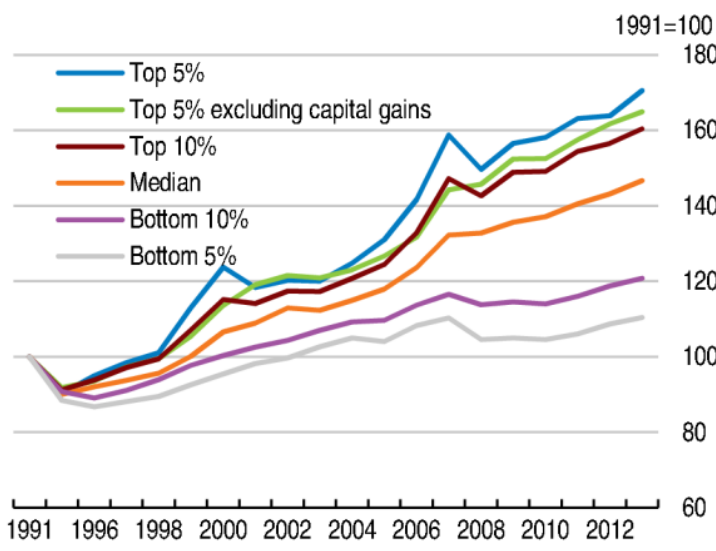

D. Work income increased more than transfers ${ }^{2}$

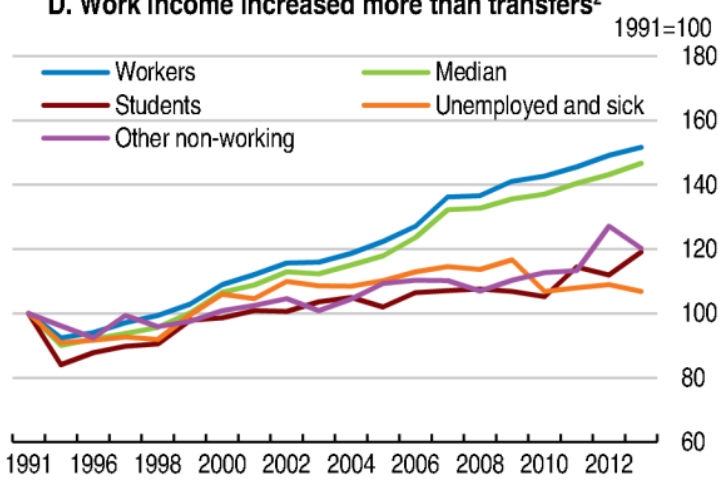

1. Equivalised disposable income.

2. Median equivalised disposable income within each group.

Source: Statistics Sweden, Income Distribution Survey; Ministry of Finance, 2016a.

The gap between earned and benefit income was widened further by the introduction of the Earned income tax credit (EITC) from 2007 and the lowering of replacement rates in the unemployment and sickness insurance, introduced to improve work incentives. However, sickness insurance spending increases rapidly despite the tightening (Fiscal Policy Council, 2016). Furthermore, higher fees to participate in occupational unemployment insurance led to outflows from such insurance in the years leading up to the Great Recession. The government has started increasing the unemployment benefit ceiling, which had fallen from above the median in 1992 to below the $10^{\text {th }}$ income percentile in 2014 (OECD Economic Survey of Sweden, 2015; Fiscal Policy Council, 2014; Ministry of Finance, 2016a). 
Incomes grew for all age groups (in real terms). However, young adults (20-29) and older individuals (65+) saw lower median income growth than others (2.3\%), since student aid and old-age pensions increased at a slower pace than earned income over the period. Couples have also seen their incomes grow faster than singles. Single mothers had the slowest income growth of all household types, with an average of $1.7 \%$ per year, as their incomes to a larger extent consist of transfers that have increased more slowly than wages. Foreign-born persons have also experienced slower income growth than natives over the period, with average income growth for those who have been in the country for less than 10 years of $1.7 \%$, and around 2\% for those with longer stays (Ministry of Finance, 2015 and 2016a).Relative poverty, measured as the share of individuals living on less than $60 \%$ of the median income followed a similar pattern as inequalities from the 1990s, and the same groups were affected. The share of the population with incomes below the relative poverty line almost doubled between 1995 and 2013 to 14\%. The incidence of relative poverty for the foreign-born and single parents increased by more than 18 percentage points, and more than $30 \%$ of individuals in each of these groups are now below the poverty line. The incidence of relative poverty among young adults (age 20-29) and single persons doubled from approximately $10 \%$ to above $20 \%$. However, the incomes of all these groups rose in real terms over the same period (Ministry of Finance, 2015 and 2016a; Figure 6).

Figure 6. Relative incomes fell while purchasing power increased in the lower part of the distribution

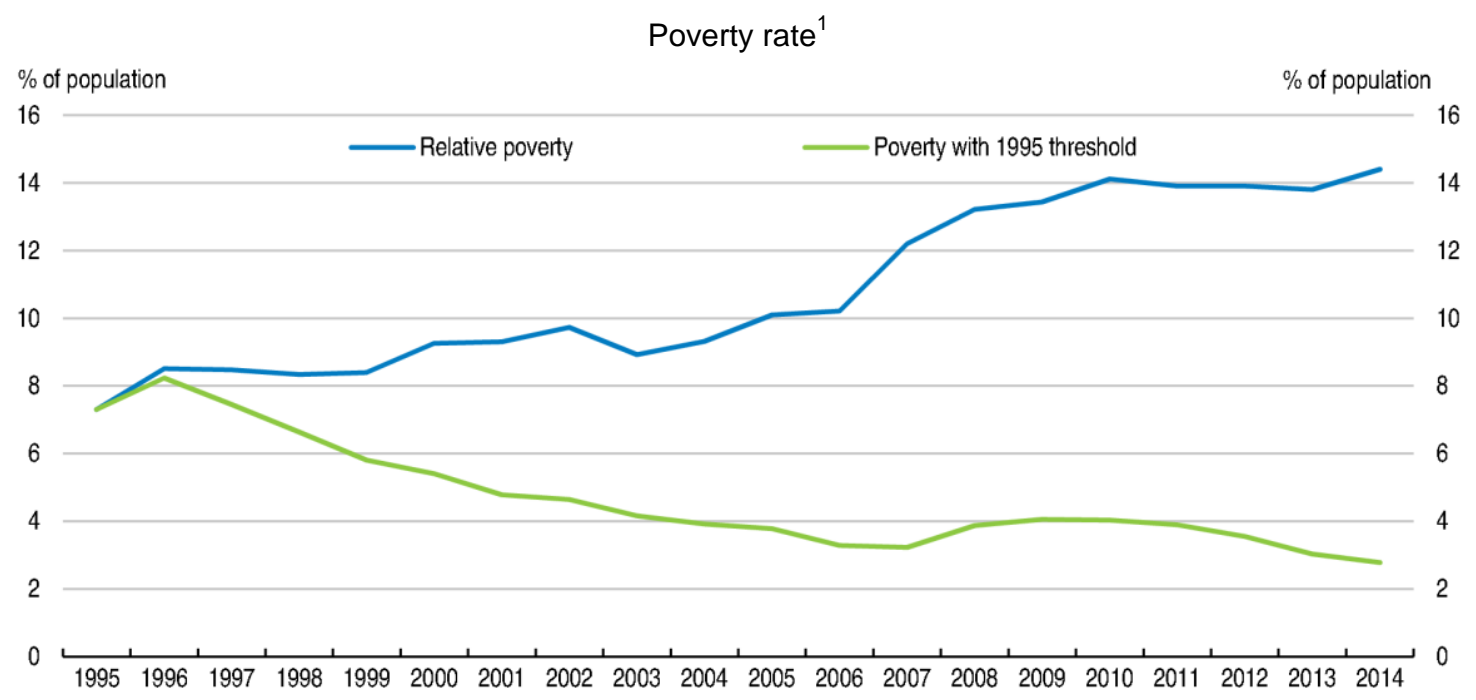

1. The relative poverty threshold equals $60 \%$ of median earnings in the year in question. The 1995 threshold equals $60 \%$ of median earnings in 1995, adjusted by the consumer price index.

Source: Ministry of Finance (2016a).

To supplement measures of relative poverty, the European Commission has adopted an index of material deprivation. Severe material deprivation is defined as the inability to pay for at least four of the following items: rent, mortgage or utility bills; adequate home heating; unexpected expenses; regular meat or protein consumption; holidays; a television set; a washing machine; a car; a telephone (Eurostat, 2016). According to this definition, only $0.7 \%$ of the Swedish population faces severe material deprivation, the lowest share in the European Union, and significantly lower than in the other Nordics (Figure 7, Panel A). Older persons, who are over-represented among persons in relative poverty, are less likely than other age groups to experience material deprivation (Figure 7, Panel B). They are likely to own their dwelling and have lower mortgage costs and more financial assets than the rest of the population, and public services, such as health care and old-age care are provided free of charge or highly subsidised.

Migrants are more likely to earn low incomes and to experience material deprivation than natives. Migrants from outside of the European Union, notably men, are more exposed than EU migrants (Figure 7, 
Panel C). Households with three or more children and single-person households are more likely to be materially deprived than single parents.

Figure 7. The incidence of material deprivation is low in Sweden

In $2015^{1}$

\section{A. Material deprivation rate}
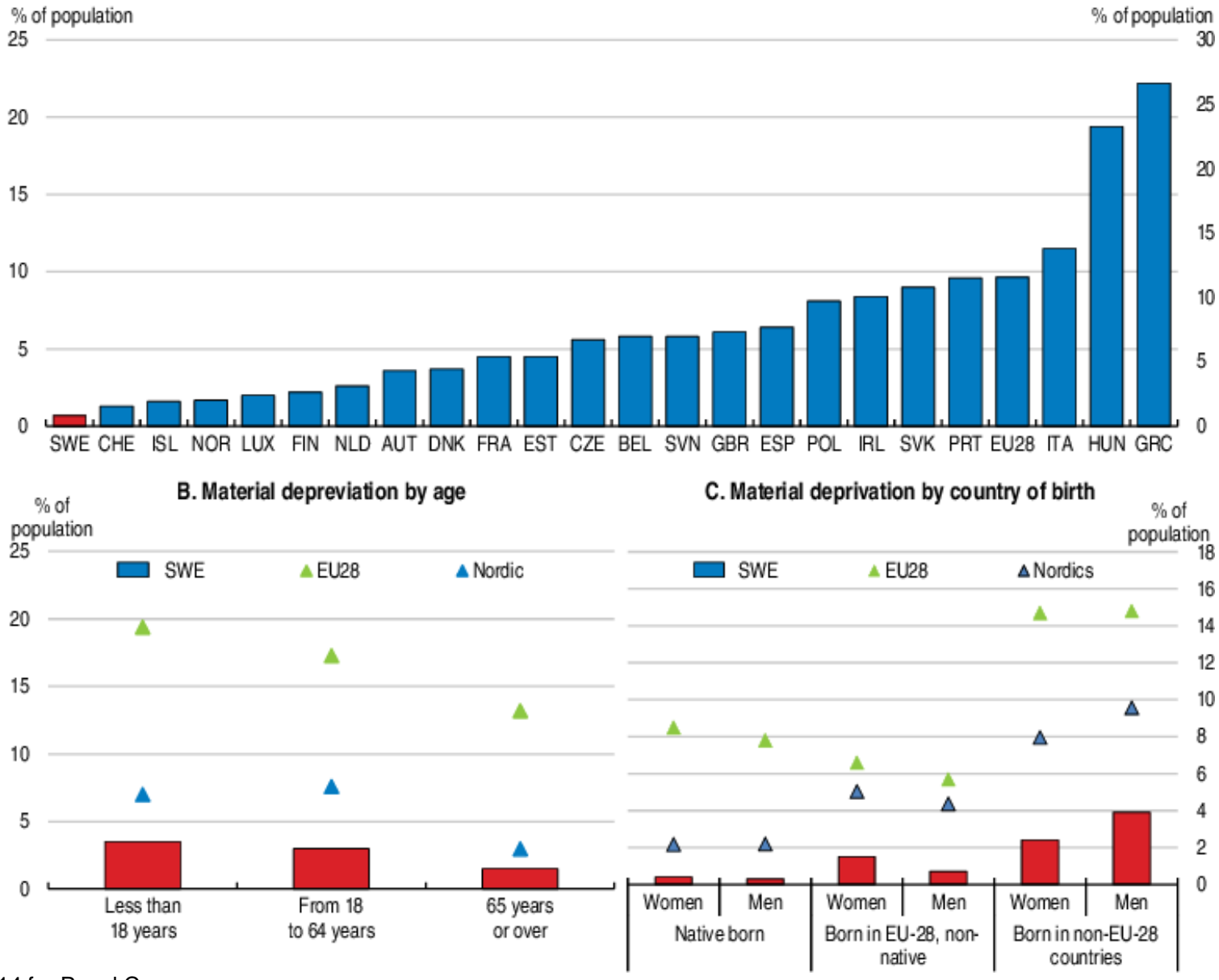

1. 2014 for Panel C.

Source: Eurostat, Income and Living Conditions database.

\section{The reforms of the late 1990s increased inequality, but brought about sustained economic growth}

The very low level of inequality in the 1980s and early 1990s was unprecedented in a historical perspective, and partly driven by rapid public sector expansion in the previous decades, government direct interventions to keep ailing industries alive, and unsustainable macroeconomic policies. These policies boosted employment in the short term but eroded competitiveness, which could only be restored through recurrent currency devaluations. In the late 1980s, a further employment boost came from rapid credit expansion and asset price increases, largely driven by the deregulation of the domestic credit market and unlimited interest rate deductions coupled with high marginal tax rates and high inflation resulting in low or negative real after-tax interest rates. Economic and financial imbalances culminated in the early 1990s economic crisis, with mass unemployment, a drop in the employment rate from $83 \%$ to $73 \%$, and a significant rise in market inequality. Taxes and transfers, however, dampened the rise in household disposable income and consumption inequalities (Domeij and Flodén, 2010). 
The product- and labour market reforms of the late 1990s helped reverse the decline that was taking place at the time, even though they also increased inequality. The breakdown of highly centralised wage bargaining in the 1980s also contributed to higher inequalities. Wage bargaining coordination was restored, but became considerably more flexible in the 1997 Agreement of Industry Development and Wage Formation which has formed the basis for Swedish wage bargaining since. The agreement stipulated common guidelines for wage setting across industries, introduced a principle of proportionality of industrial action and strengthened the powers of the national conciliator. To preserve international competitiveness, the agreement stipulated that wage rises would be set with reference to exporting industries, while there would still be flexibility to adjust wages locally within the coordinated framework. A tax reform in 1990-91 reduced the highest marginal tax rates and the value of deductions and broadened the tax base by making more types of capital incomes and fringe benefits taxable. The new income definition alone mechanically increased the Gini coefficient in 1993 by about 2 percentage points. The increase in inequality resulting from lower marginal taxes was fully offset by raising housing and child allowances (Domeij and Flodén, 2010; Elvander, 2002; Lindbeck, 1997; Björklund et al., 1995).

\section{The crisis led to better tracking of the income distribution}

The distress caused by the economic crisis of the 1990s underlined the need for analyses to assess the distributional consequences of policy, a need that the Riksdag (Parliament) had pointed out already in 1986. Sweden has long had high ambitions of using economic policy for the purpose of income equalisation. Better data and estimation methods increased the opportunity to assess policies' distributional effects, and following renewed requests from the Riksdag, the government issued the first Distribution Policy Report in 1992. The next report came in 1994, and annual (sometimes biannual) reports were issued from 1996 onwards as annexes to the annual budgets. The reports usually contain a description of the income distribution in a historical and international perspective across several dimensions, an in-depth analysis of an inequality-related subject and an analysis of the distributional consequences of government policies (Waldenström, 2012; Ministry of Finance, 2016a). Since 2011, the Fiscal Policy Council has been tasked with evaluating the distributional effects of fiscal policy in the short and the long run (Fiscal Policy Council, 2013).

\section{The uprating system led to a gradual erosion of working-age benefits}

Working-age benefits have fallen behind earned incomes because they were cut or frozen as a consequence of the 1990s crisis. Most major benefits and associated ceilings have since either been uprated according to the consumer price index, which over time grows more slowly than wages, or not systematically uprated. This has increased fiscal space and hence reduced the need to explicitly prioritise between existing expenses and new political projects. Some benefits have been increased on an ad hoc basis, others have not. Many benefits are fairly modest following two decades with this system, and a more systematic and transparent regime for uprating benefits should be considered. If benefits are systematically uprated in line with wages, the position of benefit recipients' in the income distribution compared to workers will remain unchanged in the absence of active prioritisation. However, such a system will increase fiscal costs and may reduce work incentives if wages at the lower end of the distribution rise more slowly than the chosen wage index (ISF, 2014; Sutherland et al., 2008). Alternatively, an annual process where the distributional consequences of uprating of all the main benefits are analysed systematically under different uprating scenarios, including a wage index, the CPI and no uprating, would highlight the consequences of inaction, but leave the actual increases to political discretion.

The current government has implemented policies that will likely reduce inequality. Notable benefit changes include a raised floor and ceiling for unemployment insurance, a higher sickness insurance replacement rate, a higher social assistance norm, various increases to child-related benefits and increased means-tested housing benefits for pensioners. The income tax system has also been adjusted, notably by gradually tapering the earned income tax credit on high incomes, raising the basic allowance for pensioners 
with low incomes and tightening several tax deductions. These measures are estimated to reduce the Gini coefficient by 0.4 percentage points in 2016 and increase disposable income by an average of $1.7 \%$ in the first income decile. Disposable incomes in the top $60 \%$ of the distribution are slightly lower than they would be without reforms, with a $1.4 \%$ fall in the tenth decile. Some public services have also been strengthened, notably within education and care, benefitting low-income households disproportionately. Single persons, notably single women and single parents, have gained the most from the government's policies (Ministry of Finance, 2016a).

\section{The rise in inequality was partly due to demographic and other structural trends}

During the quarter of a century since inequality bottomed out in the late 1980s, Sweden experienced significant structural change not directly related to the overall level of employment, the wage distribution or taxes and transfers. Research based on detailed micro-data shows that about $70 \%$ of the change in the Gini coefficient of equivalised market income from 1987 to 2013 can be attributed to the effect of changing household composition, age structure, industry structure, educational attainment and immigration (Figure 8; Box 2). Redistributive policies dampened the increase in inequality caused by these factors

Figure 8. Structural change increased inequalities

A. Population shares (change 1987-2013)

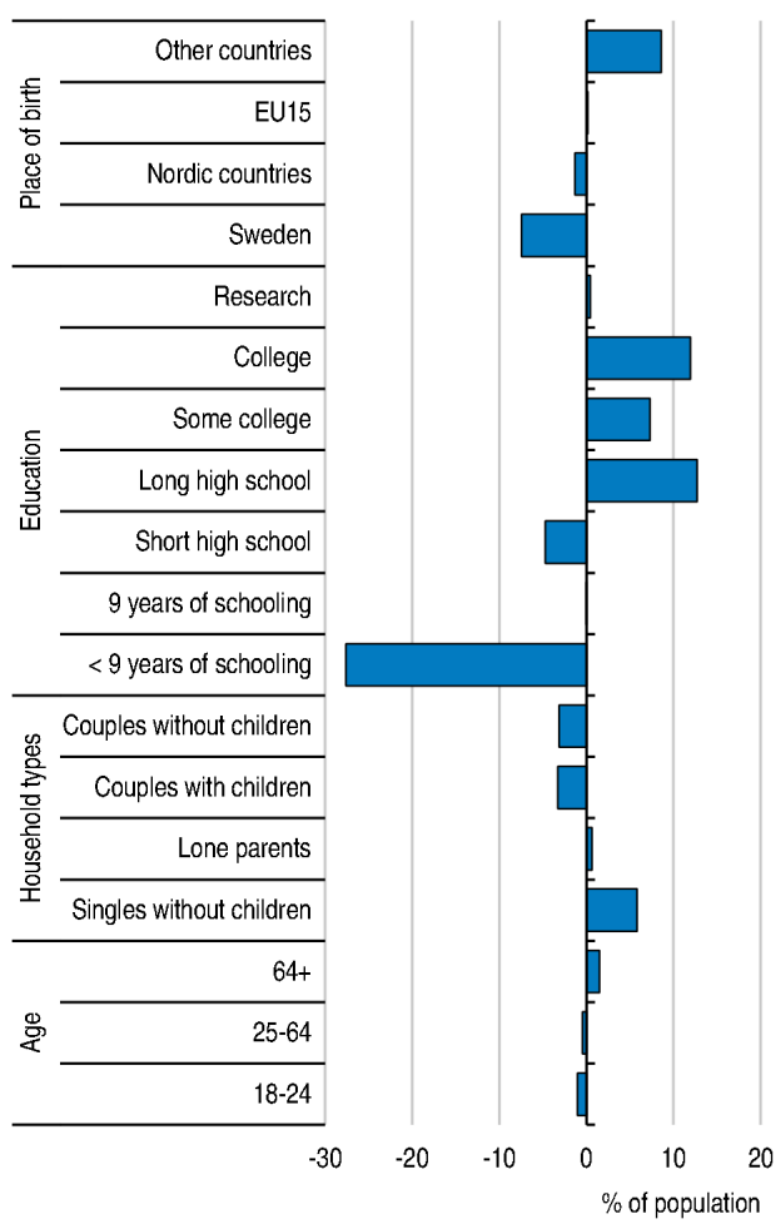

B. Contribution to inequality growth 1987-2013

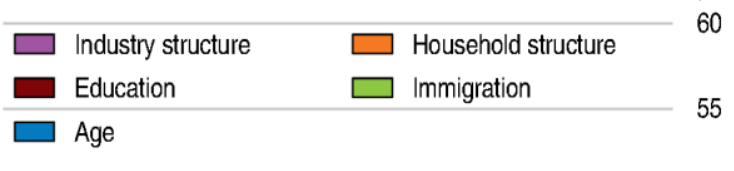

50

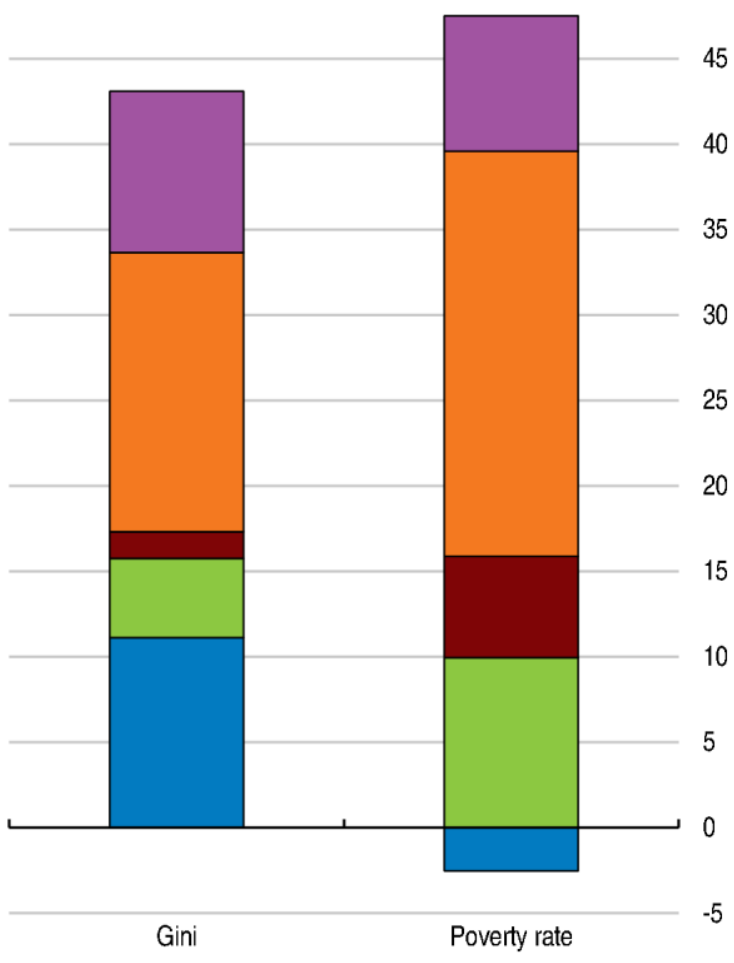

Source: Robling and Pareliussen (2017).

considerably, but the mechanical effect of changing structural factors can nonetheless explain more than $40 \%$ of the increase in the Gini coefficient of disposable income and almost half of the increase in the relative poverty rate, defined as individuals living on less than $60 \%$ of the median disposable income. 
These results should not be interpreted as contradicting other studies, pointing to forces such as weaker redistribution and higher male earnings dispersion as the main factors behind increasing inequality (e.g. OECD, 2011), but rather as complementing them. Indeed, the structural factors impact inequality through different channels, including redistribution and earnings dispersion (Robling and Pareliussen, 2017).

Household composition accounts for $16 \%$ of the Gini increase and $24 \%$ of the increase in relative poverty, largely driven by an increasing share of single and single parent households, who tend to have relatively low incomes. Marriage rates fell more steeply in Sweden than the OECD average from the 1960s, but cohabitation outside marriage is also relatively common in Sweden. Household structure has been found to increase inequalities more in Sweden than in most other countries (OECD, 2011; Robling and Pareliussen, 2017).

Ageing is less advanced in Sweden than in most other OECD countries, partly due to high immigration. Even so, age accounts for $11 \%$ of the Gini increase when taxes and transfers are taken into account, as the population share of retirement age cohorts, with relatively low incomes, increased. However, the contribution to relative poverty from ageing is slightly negative, as most pensions are uprated by a wage index and seldom fall below the poverty line (Robling and Pareliussen, 2017).

Immigration to Sweden has been high compared to other OECD countries, and with a higher share of humanitarian and family reunion migrants. However, even with non-EU migrants increasing from $3 \%$ of the population in 1987 to $12 \%$ in 2013 , migration only accounts for a relatively modest $5 \%$ share of the increase in the Gini coefficient. In contrast, it has a stronger effect on relative poverty, accounting for 10\% of its increase. However, these estimates only account for changing population shares. In addition, non-EU migrants are more likely to be young, low-qualified and single, and they have seen their average income fall considerably relative to other groups over the period (Robling and Pareliussen, 2017).

Industry structure accounts for $9 \%$ of the increase in the Gini coefficient and $8 \%$ of the increase in relative poverty, mainly as a result of the fall in relatively well-paid manufacturing employment, the rise in relatively low-paid accommodation and food services jobs, and the increase in high-paying ICT, professional and financial services positions since 1987 (Robling and Pareliussen, 2017). This supports previous research suggesting that labour market polarisation caused by globalisation and skill-biased structural change has taken place, but to a relatively limited extent, and with less important consequences in Sweden than in many other countries, as jobs lost in middle-skilled occupations have to a large extent been replaced by high-skilled jobs (Goos et al., 2009; Eurofound, 2014; Adermon and Gustavsson, 2015; Åberg, 2016).

The effect of education structure on the Gini coefficient is only slightly positive when taxes and transfers are taken into account, but the larger population share with higher education and hence higher incomes raises the median income and accounts for $6 \%$ of the rise in relative poverty (Figure 8; Robling and Pareliussen, 2017).

\section{Box 2. Structural changes and inequality}

The influence of structural changes on inequality has been decomposed with micro-data from Statistics Sweden. Subgroups of the population with certain characteristics were re-weighted by their population shares in 1987 to construct counterfactual income distributions for 2013, and inequality measures were then derived and compared to their actual 2013 values. However, when several interdependent characteristics are included, the results will depend on the sequence in which they are calculated. This is corrected for by calculating the mean contribution from all possible orderings. Results are presented in Table 2. 


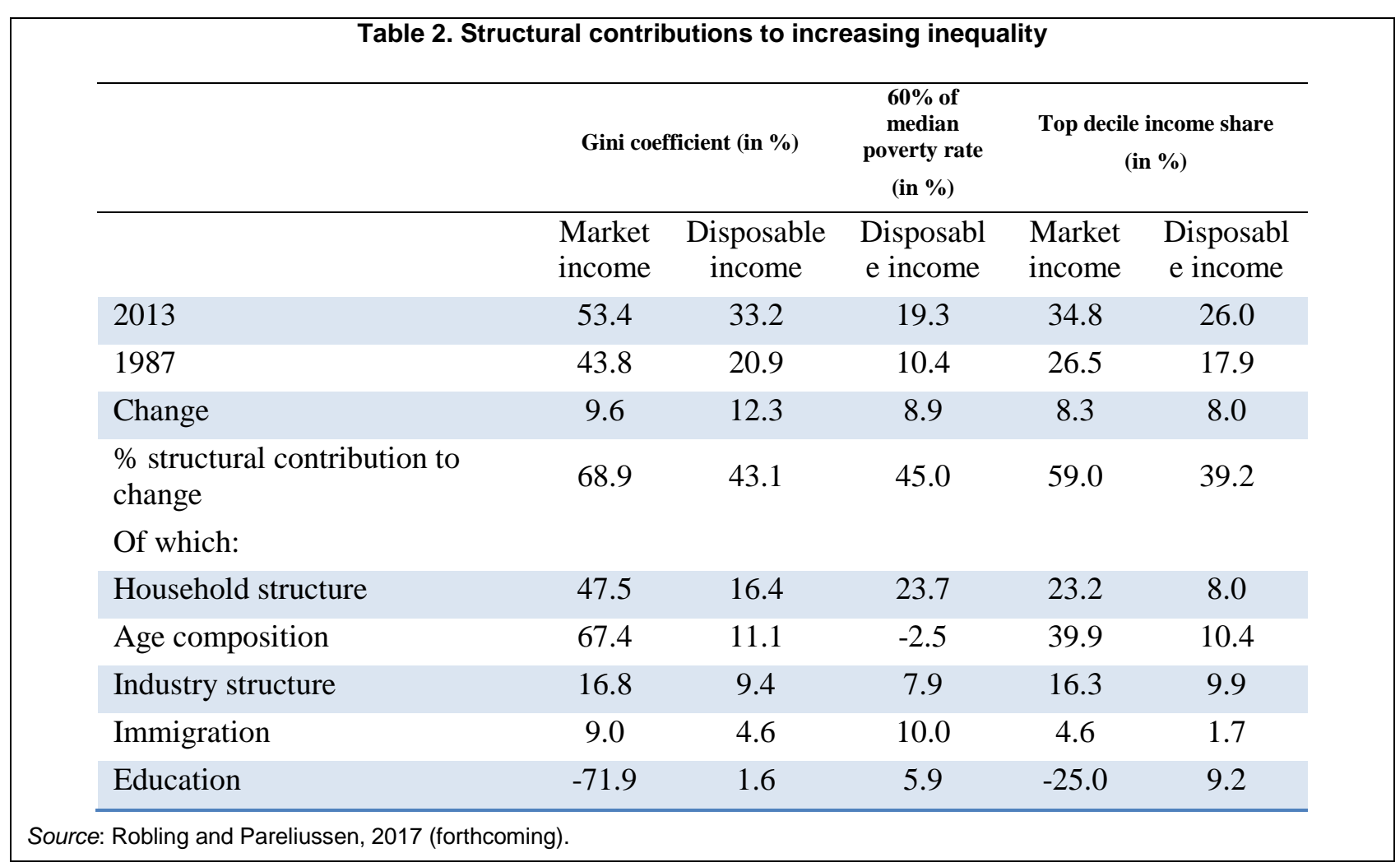

\section{Combining equity with economic efficiency}

Inequality can reduce growth, as discontent can feed voter demand for sub-optimal policies; it can lead to underinvestment in human capital by credit-strapped households; it can reduce domestic demand, as people with higher income consume a lower share of their income; and more inequality can reduce trust. On the other hand, inequalities can spur growth to the extent they result from incentives to work, undertake risk and invest, notably in education (Aghion et al., 2015). Capital accumulation by the most affluent can also lead to higher investment. Empirical studies find both positive and negative correlations between inequality and growth, depending on estimation method, inequality indicator, data and country coverage. A significant negative impact on growth from inequality at the bottom end of the income distribution has been identified across OECD countries (OECD, 2015). Lower investment opportunities for the poorer segments of the population, notably in education, is identified as an important channel. Income inequality is still low in Sweden, education is free from the first grade to university and redistribution through taxes, transfers and a wide range of public services is significant. Underinvestment in human capital because of credit constraints should hence not be a major concern in Sweden. Higher inequality, notably at the lower end of the distribution of disposable income, tends to undermine trust in people ("generalised trust"). Higher trust levels are associated with better macroeconomic performance (Gould and Hijzen, 2016).

Fournier and Johansson (2016a) find that bigger governments are associated with lower inequality and lower growth, but that the adverse effect on growth is partly offset if governments are efficient and wellfunctioning. Furthermore, increasing public investment and education spending and reducing pension spending as a share of the total can in general yield large growth gains without adversely affecting the income distribution. Shifting spending towards family benefits and child care increases growth, reduces inequality and encourages female labour force participation, particularly at the lower end of the income distribution. Cutting public subsidies boosts growth, but increases inequality in general. The scope to pursue such policies, both boosting growth and reducing inequality, is however more limited in Sweden than in most OECD countries. The size of the Swedish public sector has not changed dramatically since the 1990s, but the efficiency of public spending has improved, with a reduction in public subsidies, pension reform, reforms to sickness, disability and unemployment benefits, an expansion of the education system 
and public childcare as a statutory right from 1995 (Bergh, 2011; Gunnarsson et al., 1999; Figure 9). Simulations indicate further potential growth gains in the order of 4\% of GDP by 2060 by increasing the quality of education (measured as PISA results), and similar gains from increasing public investments and reducing subsidies as a share of total spending. Potential GDP gains from reducing the size of government, reducing pension spending and increasing family benefits are limited (Fournier and Johansson, 2016b). Such simulations provide useful illustrations, but are sensitive to the modelling framework and assumptions.

Figure 9. The evolution of the shares of productive spending and distortionary taxation

Changes over the period 1998 to 2013, in per cent of total primary expenditure and revenues

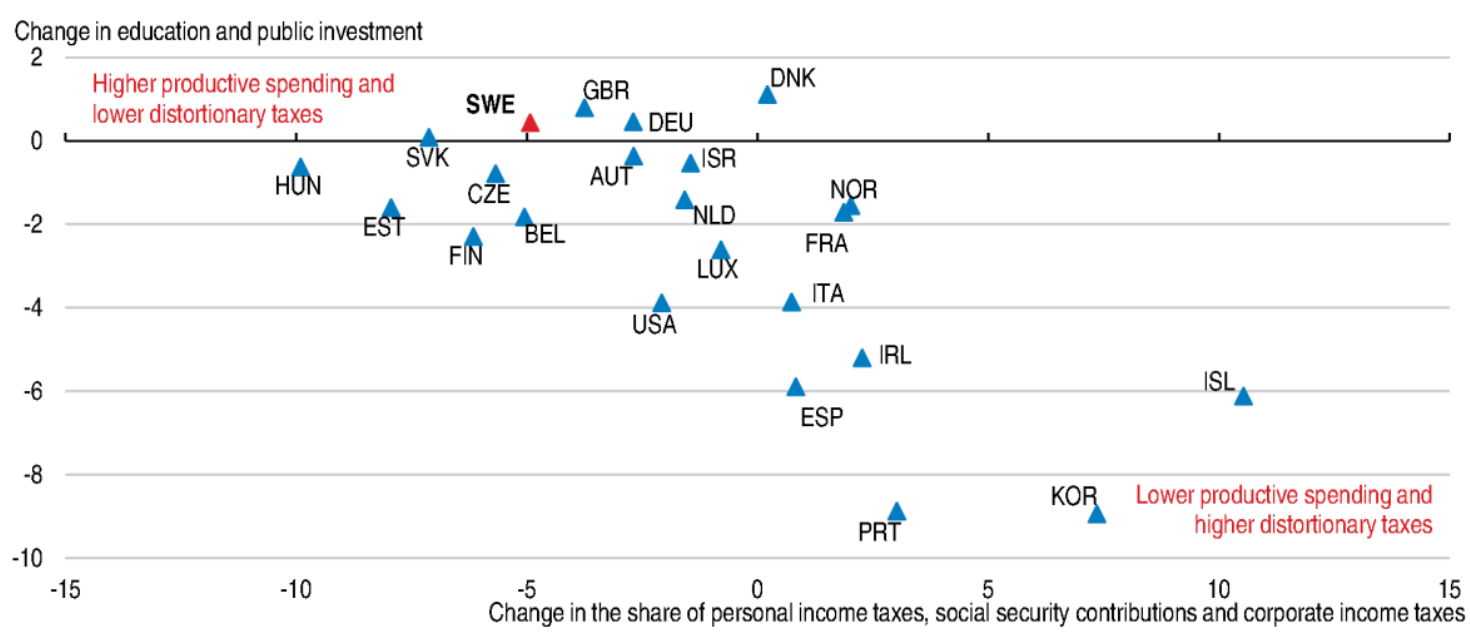

1. Education and investment data are expressed as a percentage of total primary expenditure; personal income tax, social security contributions and corporate income tax receipts are expressed as a percentage of total primary revenues.

Source: Fournier and Johansson (2016b).

\section{Wage compression, redistribution and growth}

Low inequality in Sweden is largely the result of a high degree of wage compression, high employment and the role of taxes and transfers. Wage compression and redistribution are strong drivers of equity, but can lose effectiveness if they weaken work incentives and hiring excessively, thereby lowering employment (Figure 10). Maintaining high employment and hours worked is also crucial to secure the tax revenues that are necessary for redistribution and high-quality public services.

Figure 10. The employment rate is high

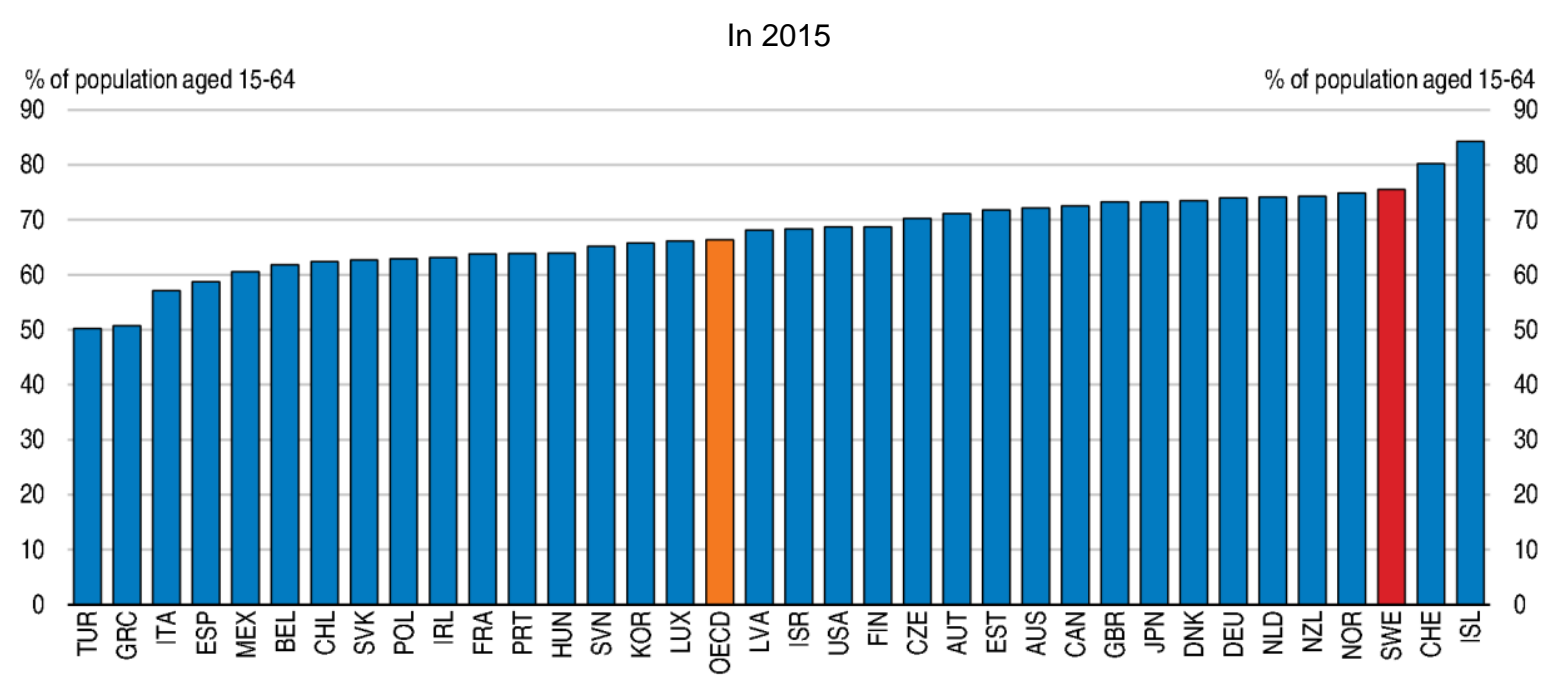

Source: OECD Economic Outlook database. 
Countries with the lowest inequalities in gross wages are also those which redistribute the most (Figure 11). Centrally coordinated wage bargaining is an important factor behind wage compression, despite significant room for local wage adjustments in Sweden, and strong unions may also influence the strength of social protection. Barth and Moene (2012) and Barth et al. (2015) show that this relation can also be explained by a multiplier effect. Wage compression is associated with a larger middle class, which tends to demand more public goods and social insurance than the well-off, who are less exposed to the risk of income losses and in a better position to self-insure. Better social protection increases the bargaining position of marginal workers, which reinforces further wage compression.

Wage compression and redistribution, coupled with active labour market policies, can create favourable conditions for inclusive growth. Compressed wages and redistribution may weaken incentives to invest in human capital and to shift jobs, and a large public sector may reduce productivity growth. However, free higher education reduces the private cost of building human capital. Social benefits and largely free public services serve the dual purpose of redistribution and risk pooling. Reducing the individual cost of job losses increases risk-taking and acceptance of structural change. Many benefits also incentivise labour participation, as they depend on work history. Reasonable benefit levels can therefore make an economy more dynamic. Even so, these positive effects do not apply to individuals on passive benefits, and activation of the unemployed is important to counteract reduced work incentives. Several reforms in the past decade to limit access to passive benefits are therefore welcome. However, as individuals are increasingly and for the most part rightly classified as job seekers, structural unemployment (and labour market participation) has gone up. Sweden has a well-designed job-search conditionality regime, with regular activity reporting and gradual sanctions for non-compliance. Intensifying matching measures such as coaching, guidance and specialist assessments should cater well for individuals close to the labour market. But more marginal groups, such as the low-skilled, migrants and those with long absences from working life, may need additional and more targeted activation measures, such as job practice, training and rehabilitation (OECD Economic Survey of Sweden, 2015).

Figure 11. Countries with low gross earnings inequality also tend to have higher social spending

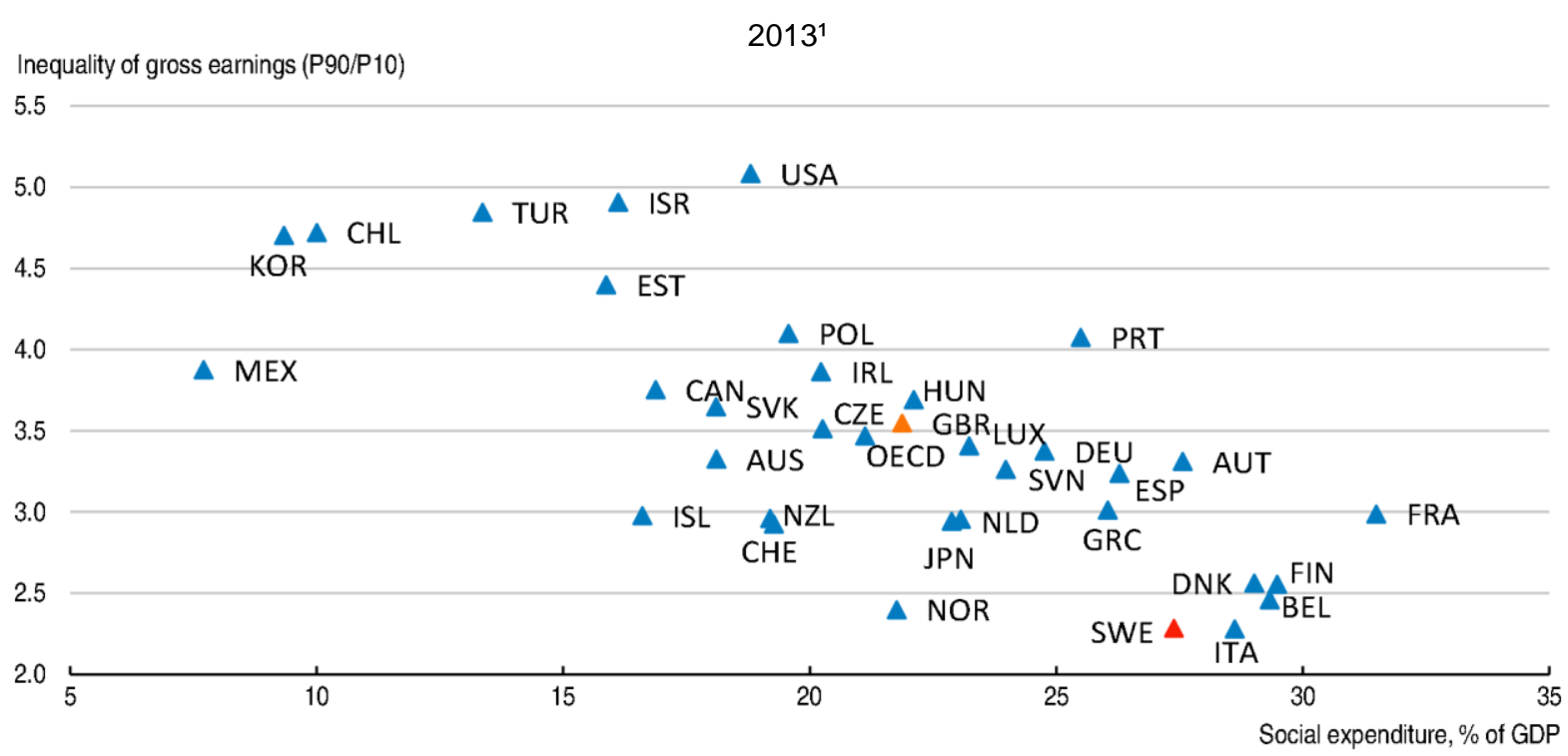

1. 2011 for inequality of gross earnings of Estonia, France, Luxembourg, Netherlands, Poland, and for social expenditure of Mexico.

Source: OECD Earnings Statistics database and OECD Social Expenditure database.

Wage compression can also contribute to structural change. The returns to productivity-enhancing investments increase, as gains at the company level do not fully translate into higher wages. Companies with low productivity are forced to invest or scale down. Investments in human and physical capital are 
therefore incentivised, as is the transition of workers from ailing to growing companies and industries. Two-tier collective bargaining, where central coordination is combined with a significant part of wage increases negotiated locally, also provides some flexibility locally and between industries (OECD Economic Survey of Sweden, 2015). Despite this flexibility, high entry-level wages make it difficult to employ low-skilled workers.

\section{Absorbing the increasing supply of low-skilled workers is challenging}

The compressed wage structure in Sweden requires relatively high skills and at least a secondary education to pass the threshold to enter the labour market. Compression in the lower part of the wage distribution can be combined with high employment, since productivity is high even at the low end of the human capital distribution. However, skills and qualifications required to gain employment are difficult to match for some. Thirteen percent of Swedes aged 16 to 64 scored at or below level 1 in the literacy test of the OECD Survey of Adult Skills (PIAAC) in 2012, and the employment rate of individuals with weak literacy is low, both compared to high-skilled Swedes and to the average participating country in PIAAC (Figure 12).

Figure 12. Employment opportunities for the low-skilled are limited In 2012

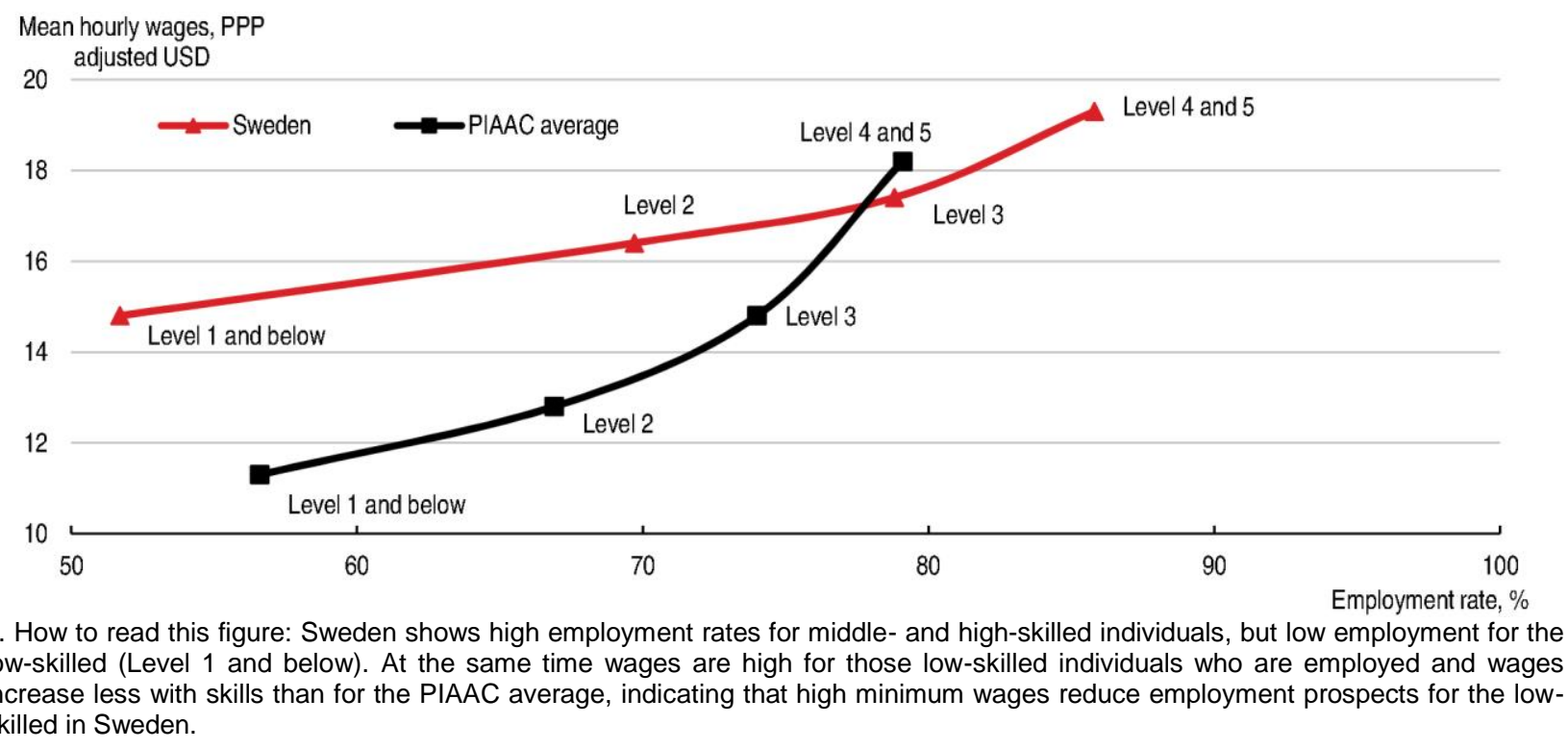

Source: OECD Survey of Adult Skills (2012).

Low literacy skills, however, is a marginal phenomenon among native Swedes, whose skills have been nurtured by relatively high-quality schooling. Even so, a trend of falling learning outcomes for the past few decades, and the dramatic deterioration in 15-year olds' OECD Programme for International Student Assessment (PISA) scores until 2012 suggests that younger cohorts are doing less well than their predecessors in international comparison (OECD Economic Survey of Sweden, 2015). This trend now seems to have been broken, as Sweden improved results in all three subjects in PISA 2015. Migrants from high-income European countries, the United States and Canada, are also unlikely to score at or below 1 in the PIAAC literacy test, and their literacy scores are in general not far below natives for a given education

level, despite taking the test in Swedish (Figure 13, Panel A). They are somewhat less educated than natives, but have significantly higher qualifications than Asian, African and European migrants from outside the European Union (Figure 13, Panel B). These migrants mostly arrived to Sweden for humanitarian and family reunion reasons, which is generally associated with more difficulties to integrate 
into the labour market than migration motivated by work or studies. Migrants with education and skills that are lower and less adaptable to the labour market needs in a destination country (less portable) will also have an incentive to migrate to countries with more wage compression and higher benefit levels (Pareliussen, 2017 forthcoming).

Figure 13. Migrants have lower education and literacy than natives
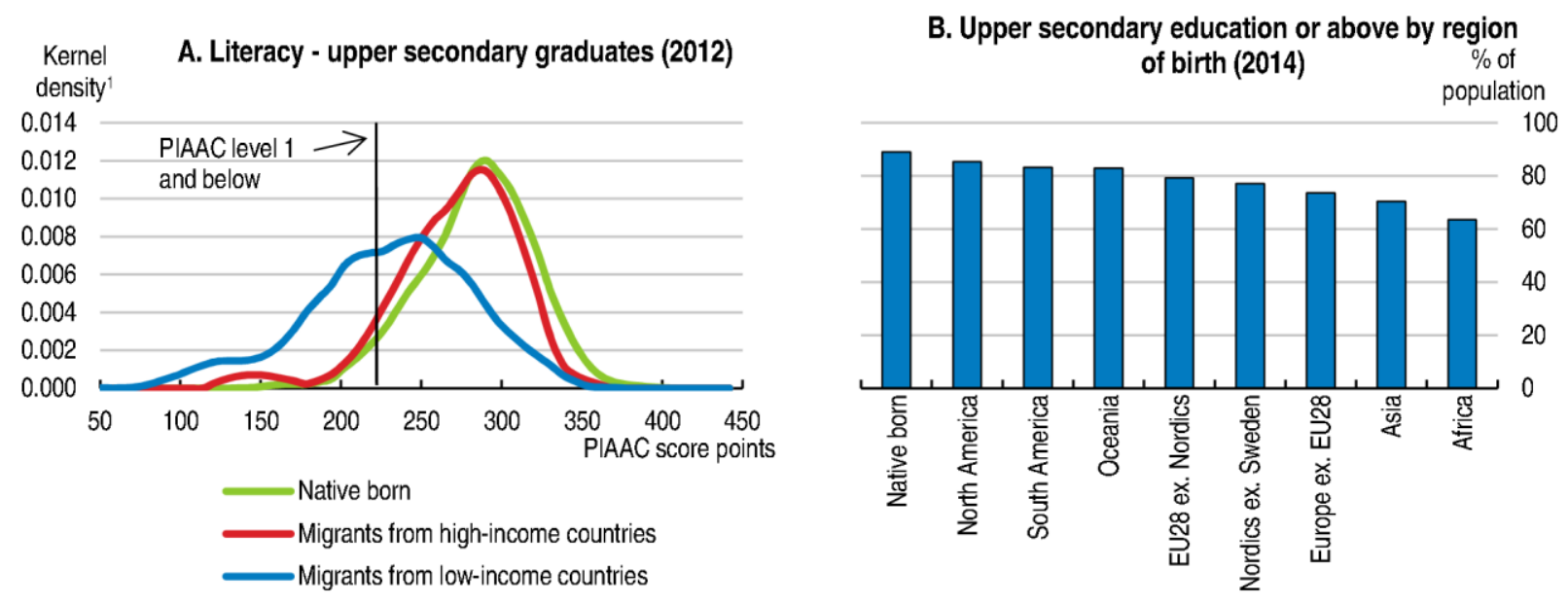

1. The Kernel density is estimated using the Epanechnikov function.

Source: Statistics Sweden and the OECD Survey of Adult Skills.

The share of foreign born in Sweden has risen from $7.5 \%$ in 1980 to $16 \%$ in 2015 . At the same time the composition of the migrant population has changed from mainly Nordic work migrants working in the manufacturing industry in the 1980s towards largely humanitarian and family reunion migrants (Figure 14).

Figure 14. Non-labour immigration is high

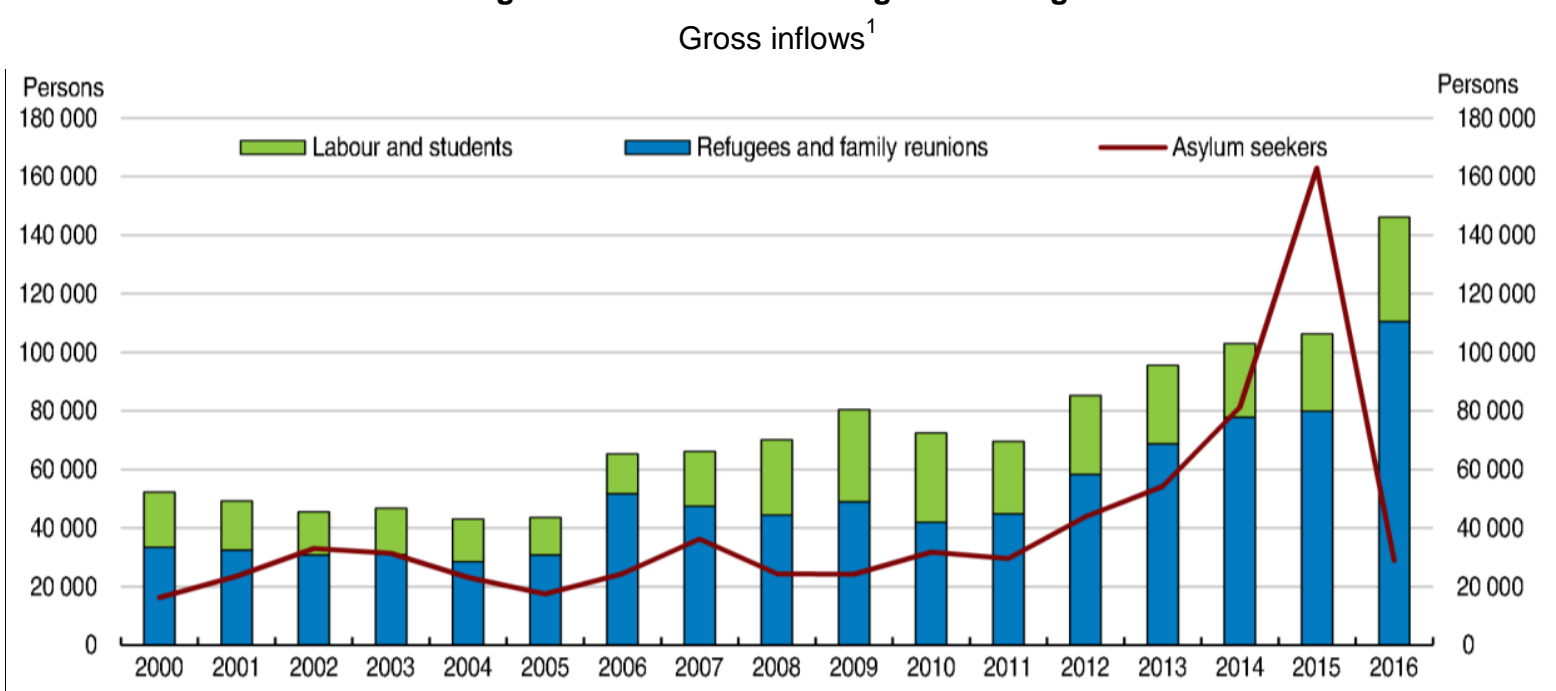

1. Excluding free movement immigrants from EEA countries.

Source: Swedish Migration Agency.

Estimates suggest that about half of the current foreign-born population originally came to Sweden as refugees or as the family of refugees. Inflows of asylum seekers relative to the population have been the highest in the OECD in the latest years (OECD, 2016a). About 160000 asylum seekers reached Sweden in 2015. However, inflows decreased to around 30000 in 2016, mostly as a result of external factors, even though the tightening of immigration policy also contributed. 
Migration affects inequalities in several ways; directly, as migrants have different career profiles than natives, with lower earnings and employment; and indirectly, as labour market competition affects employment and earnings of natives, notably those in low-skill occupations (Robling, 2015; Robling and Pareliussen, 2017). Robling (2015) finds a negative employment effect of non-Nordic migration, which roughly doubles migration's direct impact, and explains more than $10 \%$ of the increase of the Gini coefficient and $20 \%$ of the increase in relative poverty since the 1980s. Engdahl (2016) finds a limited negative short-term effect on employment and wages, mainly driven by migration from the other Nordics, who are closer substitutes to Swedish labour. Low-educated natives and earlier migrants are particularly vulnerable to labour market competition from new migrants. Long-term labour market effects should be less pronounced, as firms will adapt their production structure, individuals will adapt their investments in human capital, and migrants may bring new ideas and open new trade linkages.

\section{The settlement of migrants takes too long}

The migrant surge in 2014 and 2015 created backlogs in the treatment of asylum applications and issuance of residence permits, a process that lasted 125 days on average even in 2013, before the surge. Backlogs should abate going forward as funding has been increased and the number of new asylum seekers has plummeted. Asylum applicants are allowed to work under certain conditions, and they will be offered 40 hours of language training. Reducing backlogs, increasing access to and volume of language tuition as well as civic orientation classes should be prioritised going forward.

A cumbersome administrative process starts once a residence permit has been issued. The responsibility for integration is then transferred from the Migration Board to the Public Employment Service in order to start the two-year Introduction programme with language classes, upskilling and labour market activities and access to the Introduction benefit (OECD, 2016a). However, the Introduction programme does not start until the individual has found permanent residence, and normally the programme does not start until a social security number is issued by the Tax Agency. Time needed to obtain a social security number can be substantial, and the number is not issued until the migrant has found permanent residence. Migrants can find their own housing, or they will be allocated housing by the PES. Housing allocation is supposed to be determined by where their education and experience are best matched to the employment needs of the local municipality, but in practice it has been determined by the availability of housing and preferences of municipalities regarding the number of migrants to accept. Waiting times for housing allocation are long, and compensation from the government to municipalities is not always reflecting the true cost of settlement (OECD, 2016a). All municipalities have from March 2016 been obliged to accept migrants, which may ease the situation. Migrants need to register with the Social Insurance Agency to obtain child support, parental leave benefits and dental care support, and they also need to register with the social services of the municipality of residence (Swedish Social Insurance Agency, 2016).

A pilot project "Meeting points and information" involving among others the Migration Board, Tax Authority, PES, Social Insurance Agency, Pension Agency and the Association of Local Authorities and Regions, gathered the most important actors in the settlement process in municipal Service Centres at the same time, with a checklist of processes to be completed. The project reduced the process from about four weeks to four hours, improved cooperation between different institutions and their understanding of the settlement process and increased migrants' confidence and sense of control of their situation. Public savings due to efficiency gains were found to be substantial. This way of working is to be gradually rolled out nation-wide (Swedish Social Insurance Agency, 2016; Ministry of Employment, 2016). The large gains from reducing the settlement time by only four weeks illustrates the potential to be reaped from streamlining and removing bottlenecks in the asylum, settlement and integration processes. Faster settlement means speedier integration and employment, better lives and longer working careers for 
migrants. Major remaining bottlenecks for migrant settlement are related to obtaining a residence permit and a social security number and to finding housing.

\section{Raising migrants'skills}

Once low-skilled migrants are settled, the Swedish policy response to increase their employability rests mainly on two broad pillars: upskilling and enhancing transparency on migrants' skills on the one hand, and temporarily lowering the cost of hiring by means of wage subsidies on the other (OECD, 2016a). The importance of up-skilling, starting with language is evident. The employment gap between migrants and natives is well accounted for by migrants' education and literacy proficiency, as measured in PIAAC (OECD Economic Survey of Sweden, 2015; Bussi and Pareliussen, 2015). Swedish tuition for immigrants has been made more flexible and municipalities should use this flexibility to better adapt teaching to the initial education and skill level of the individual migrants, which is very heterogeneous. More resources are set aside to improve recognition of foreign qualifications, notably with several fast-track schemes for occupations with a labour shortage, and the government intends to broaden newly arrived migrants' access to trainee and vocational introduction employment. Likewise, newly arrived migrant children need close and adapted follow-up from their schools, as their level of schooling varies, and those who arrive at the late stages of compulsory school perform relatively poorly (Ministry of Finance, 2016b; OECD, 2016a). It is too early to quantify the effects of many of these recent reforms, but a major reform in 2010, placing responsibility of integration with the PES improved migrants' employment and earnings significantly (Andersson Joona et al., 2016).

\section{Incentives to hire the low-skilled}

In addition to raising skills, thresholds to employment need to be overcome. Declining school results and high humanitarian and family reunion immigration increase the supply of low-skilled labour, while wages in sectors that typically employ the low-skilled are relatively high, dampening job creation in these sectors (OECD Economic Survey of Sweden, 2015). Minimum wages are set sector-wise in collective bargaining, and are below market wages in most sectors. Low-skill service sector jobs, such as retail trade and hotels and restaurants are notable exceptions. Workers and employers in these sectors are less likely than average to belong to unions, but the wage floor in non-organised segments generally seems to be close to the level set by collective agreements. Low-skilled jobs account for only about $5 \%$ of total employment (OECD, 2016a). In industries where the minimum wage is binding, workers with low skills and a weaker labour market position are squeezed out if the minimum wage increases (Forslund et al., 2014; Eliasson and Skans, 2014).

Much has already been done to cut the wage bill by means of tax policies and wage subsidies. The income tax basic allowance and the earned income tax credit incentivise work for low-wage earners. Wage subsidies are available in multiple forms and shapes, and can be an efficient tool to raise the employment prospects of immigrants, when gradually phased out. But the take-up of such subsidies is low among employers, due in part to limited awareness and in part to the administrative burden associated with multiple programmes that may fit migrants at different stages of the integration process. The Public Employment Service is increasingly marketing the different wage subsidies as a package of measures, enabling a gradual phasing out of the wage subsidy as the employability of migrants increase over time. However, to increase the scale and effectiveness of these measures, they will need to be harmonised and streamlined in order to increase oversight and reduce the administrative burden they impose both on employers and Public Employment Service caseworkers (OECD, 2016a).

Tax credits and wage subsidies come with a fiscal cost, which limits the possibilities to extend them. Lowering entry-level wages in combination with higher rewards to work experience should be considered by the bargaining parties in the sectors concerned, as it would lower entry thresholds, while preserving life- 
time incomes. The link between minimum wages and inequality is complex. The net effect depends on the wage effect for those employed, the impact of entry thresholds on employment and incomes over the life cycle (Labour Market Economic Council, 2016).

\section{Employment protection}

Employment protection legislation (EPL) for regular contracts in Sweden is fairly strict despite a generous social safety net, but collective agreements may allow some flexibility. The legislation includes heavy notification procedures in case of dismissal, stringent regulation of the order of layoffs in case of redundancy, a relatively broad definition of unfair dismissals and sizeable compensation following such dismissals. When cases go to court, the procedures are long. By contrast, employers can use temporary contracts with few constraints. This adds flexibility for Swedish employers, but can disadvantage vulnerable groups such as the low-skilled and immigrants. Reducing the stringency of employment protection on regular contracts would lower thresholds. Individual income losses for some groups following a higher rate of job separations would be partly offset by the unemployment insurance and Sweden's well-developed activation policies (Figure 15; OECD Economic Survey of Sweden, 2015).

\section{Figure 15. Employment protection is relatively strict ${ }^{1}$}

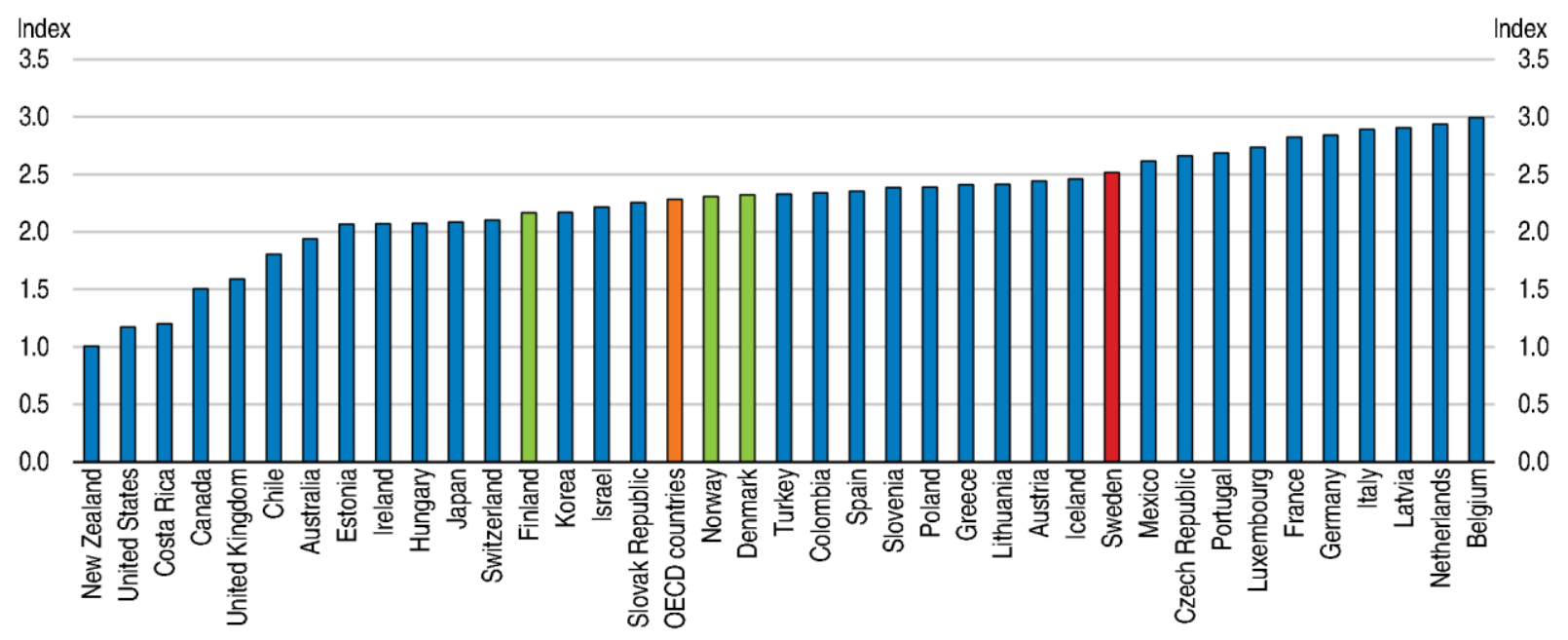

1. Index scale of 0-6 from least to most restrictive.

Source: OECD, Employment Protection Database.

Increasing flexibility for regular contracts can facilitate transitions from joblessness to employment in countries with well-designed activation policies, such as Sweden. A typical flexibility-enhancing reform, as measured by the average change in the OECD EPL indicator for permanent workers, increases average job-finding rates over the five years following reform by an estimated 10 percentage points if the Public Employment Service is well-funded (30\% higher spending than the OECD average per unemployed worker or more). However, more flexibility also likely increases transitions from employment to joblessness. This effect is smaller in magnitude, about 2 percentage points, but is observed fairly early following a reform. Transitions from joblessness to employment take more time to materialise, and groups with weaker attachment to the labour market, such as young people and women, benefit more than average. The short-term negative effects of EPL reform are lower and more short-lived if the reform is undertaken in an expanding economy, and also if the share of employees on fixed-term contracts is high (Cournède et al., 2016; OECD, 2016b). Positive and negative effects of EPL reforms are likely to be lower in Sweden, since many sectors have already increased flexibility by collective agreement. 


\section{Residential and school segregation}

Intergenerational social mobility is generally high in Sweden, but comparing how parents and offspring are placed in the earnings distribution as adults requires very long time series (Bjorklund et al., 2009). Evidently, such estimates only capture mobility with a substantial lag, and among families that have resided in Sweden for several decades. On many indicators, children of immigrants, notably those who are native-born, fare better in Sweden than in other European OECD countries, even though immigrant adults face challenges. However, the imperfect labour market integration of their parents together with residential and school segregation still reduces opportunities for migrant children compared to natives (OECD, 2016a).

$12 \%$ of immigrants and native-born with two immigrant parents live in 38 increasingly overcrowded suburbs, built as part of The Million Programme, a large-scale programme to respond to housing shortages in the 1960s and 1970s. On average, three quarters of the inhabitants in these 38 suburbs have a foreign background. Natives and the more successful migrants have increasingly moved elsewhere, which has increased the concentration of low-income migrants. The employment rate is 22 percentage points below the national average, the shares of unemployed, inactive and social support recipients are also all between double and triple the national average. Education levels and health outcomes are low compared to the national average (Edling, 2015). Higher crime rates amongst minorities are partly explained by segregation. The effect is highest among children with low-educated parents, and weak labour market attachment is a partial explanation of the differences with natives (Grönquist et al., 2015).

Publicly funded education is one of the few areas where policy can act to level the playing field and create equal opportunities for children with different family backgrounds. School choice reforms in the early 1990s moved Sweden from a system with virtually no choice and no private alternatives, to a voucher-based system where funding follows the pupil, with choice between public and private, but publicly funded, so called "independent" schools (OECD Economic Survey of Sweden, 2015). As of today, about $12 \%$ of 16-year old pupils attend an independent school. Results from PISA 2015 indicate that the impact of socioeconomic background on learning has increased. Higher variation between schools is affected both by the pupils' own backgrounds, including migrant background and parental education, and by the average socio-economic mix in the school (SNAE, 2016). Variation between schools seems to be driven mainly by residential segregation. School choice also contributed to increased school segregation, but to a relatively limited extent (Böhlmark et al., 2015; Holmlund et al., 2016). Additional funding to schools with disadvantaged students is generally subject to municipal discretion, and not sufficient to compensate for the student mix or to attract the best teachers (OECD Economic Survey of Sweden, 2015). However, the government has implemented measures to strengthen early interventions for struggling pupils and educate more special-needs teachers, and more resources have been channelled to schools with low learning outcomes (Ministry of Finance, 2016b).

Municipalities are responsible for important aspects of migrant integration, notably language training, adult education, social assistance and compulsory school. The approach to and quality of these services therefore vary considerably across the country (OECD, 2016a). Some Swedish municipalities, such as Södertälje, a city of almost 100000 persons south-west of Stockholm, already have considerable experience with migration. Almost $40 \%$ of the population is today foreign-born, after annual immigration of between $1.5 \%$ and $2 \%$ every year since 2006 . This led initially to declining school results, strained finances, overcrowding and increased residential segregation. Skills were identified as a main challenge, and systematic efforts to improve school management at the municipal and school level, active teacher and school leader recruitment strategies as well as actively steering new migrants towards schools with capacity to accept them, have born results. The municipality has climbed substantially in national school rankings since 2009-10, and finances have improved due to efficiency gains and a tightening of social assistance to the national minimum standard. Challenges remain, but systematic efforts to draw on the 
experience of municipalities such as Södertälje, identify and disseminate best practices, hold the potential to improve integration (OECD, 2016a).

\section{Rent control comes with a high social cost and no obvious benefits}

Structural weaknesses in the housing market, besides creating vulnerabilities related to rising housing prices and household indebtedness, reduce mobility with adverse effects on employment, well-being, competitiveness and productivity growth. Limited opportunities for households to find affordable housing in areas where jobs are available hamper social mobility for individuals with low initial income and wealth, notably migrants. The current favourable tax treatment of owner-occupied housing reduces affordability by driving up housing prices and favours high-income households. It also leads to a high rate of home ownership (Figure 16). Increasing the property tax ceiling or phasing out mortgage rate deductibility would be clearly redistributive and would increase the efficiency of the tax system (Fiscal Policy Council, 2016). Cumbersome land-use planning regulations and low competition in the construction sector hold back housing supply and contribute to rising housing costs. In March 2015, the government announced an ambitious plan supporting dwelling construction, which aims at ensuring that $250000 \mathrm{dwellings}$ are built over the period 2015-20. The plan provides subsidies for rental housing, which are targeted at demographic growth areas and are highest for small flats and student dwellings, for which the shortage is most acute. The subsidies are conditional on maximum rent requirements for 15 years (varying between areas) and stringent energy efficiency norms. The cost is estimated at SEK 6.7 bn (0.2\% of GDP) per year and will be financed by cutting tax breaks for domestic building work, including home improvement. The government will work with municipalities to reduce completion-time for housing projects, through improving the efficiency of land-use planning and regulations. Incentives for municipalities to encourage construction will be enhanced, notably through increased state financing for related infrastructure. However, it will remain challenging to get enough housing built to respond to demand and accommodate the large flow of immigrants in a way that minimises spatial segregation (Adalet McGovan, 2013; OECD, 2016a). Unfortunately, a recent government initiative to gather cross-party agreement on broader housing market reforms ended in failure.

Figure 16. Owner occupied housing

$2015^{1}$

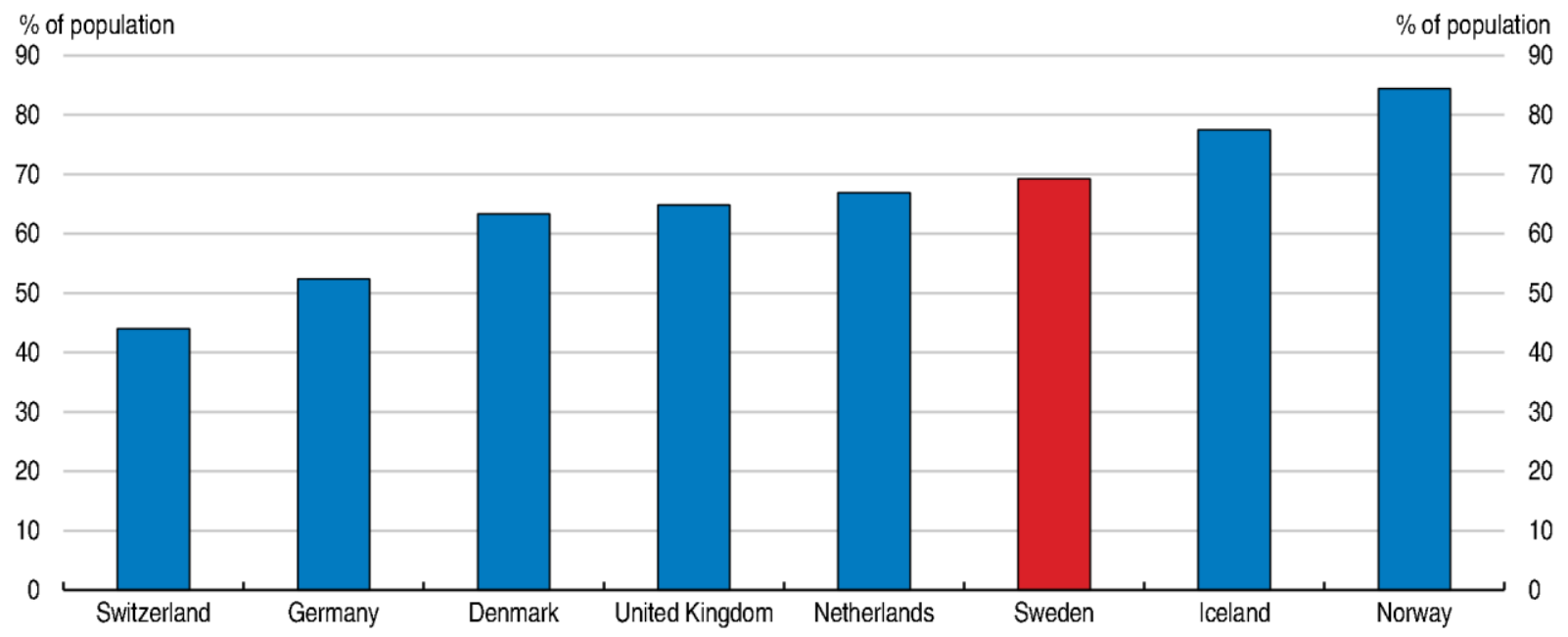

1. 2014 for Switzerland.

Source: Eurostat, living conditions and social protection database.

Like in most countries, individuals with low incomes and equity are mostly confined to the rental market, especially in cities. But the rental market in Sweden stands out internationally for strict and all- 
encompassing rental regulations, resulting in limited mobility, a significant welfare loss and a sizeable black market for rental dwellings in the main metropolitan areas (Enström Öst et al., 2014; Andersson and Söderberg, 2012; Lind, 2015; Housing Crisis Committee, 2014). While costs are significant, there are no obvious gains to society from the current system. The socio-economic gradient of overcrowding is among the highest in the OECD (Figure 17). However, significant private gains occur to those existing tenants who possess valuable leases with low rent, and this group is well-organised in tenant unions.

Rent control, like in many other OECD countries, was introduced as an emergency measure during the Second World War. Even though the system has been amended over time, it remains relatively rigid and holds rents below market values in the most desirable locations, leading to a shortage of housing, notably in the Stockholm area. The same rules apply to rental dwellings owned by private landlords and municipal housing corporations. The rent level is set in collective rent negotiations between property owners and the Swedish Union of Tenants and enforced by rental tribunals. Rents are set according to the quality, standard and service of the apartment, and in practice rents vary mainly according to the age of the building, not its location. The main allocation mechanism is a waiting list (Enström Öst et al., 2014). More than 500000 persons, or 5.2\% of the Swedish population, were registered in the Stockholm region waiting list at the end of 2015, and the average waiting time was 8.2 years (Figure 18). Waiting lists in other Swedish cities are shorter, since rents are somewhat better aligned with market values.

Figure 17 . Overcrowded housing is fairly common in the bottom $20 \%$ of the income distribution

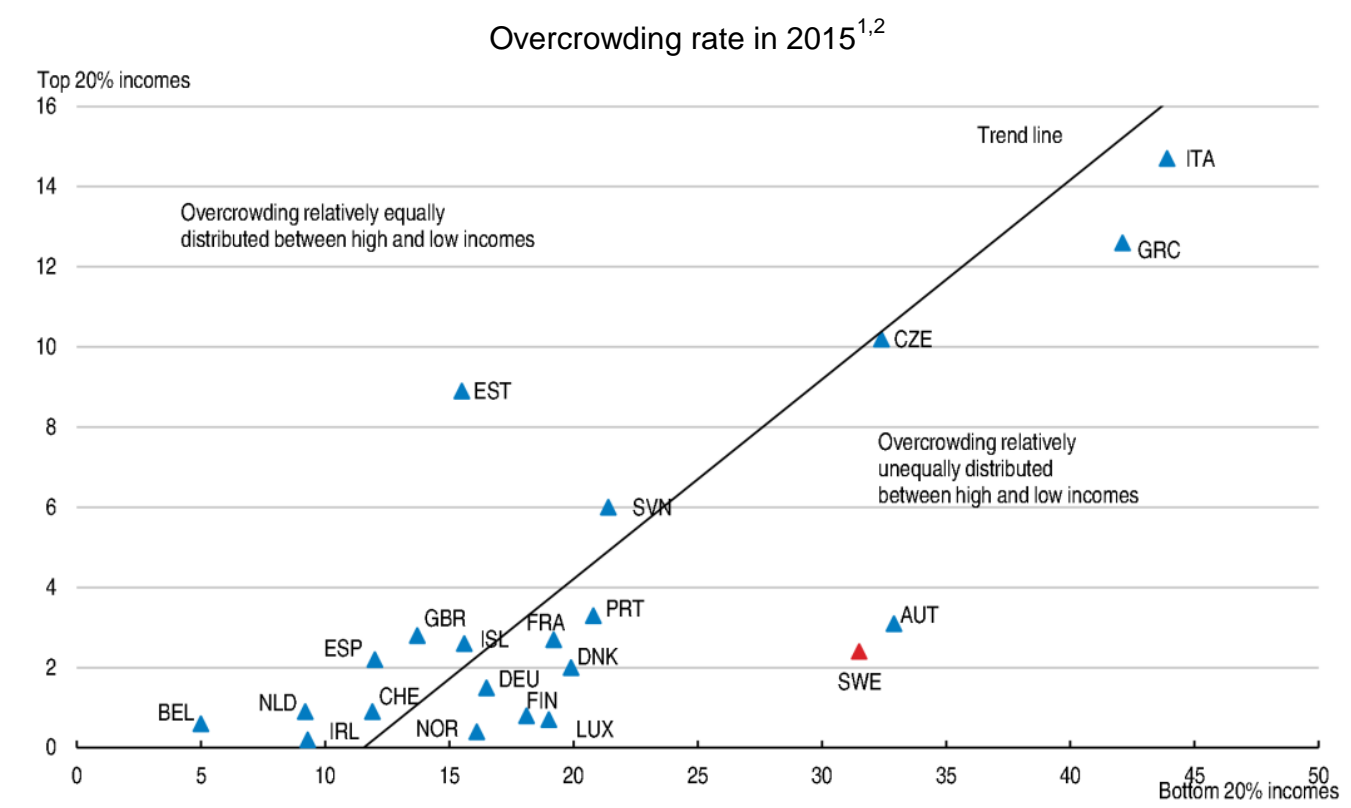

1. The overcrowding rate is defined as the percentage of the population living in an overcrowded housing unit. A person is considered as living in an overcrowded housing unit if the household does not have at its disposal a minimum number of rooms equal to: one room for the household; one room per couple in the household; one room for each single person aged 18 or more; one room per pair of single people of the same gender between 12 and 17 years of age; one room for each single person between 12 and 17 years of age and not included in the previous category; one room per pair of children under 12 years of age.

2. 2014 for Ireland and Switzerland.

Source: Eurostat, Income and Living Conditions database.

Even though the policy objectives behind Swedish rental regulations are not clearly stated and have evolved over time, they include providing affordable and high-quality housing, limiting spatial segregation and protecting tenants from abuse by landlords, such as sudden rent hikes or evictions. 
Figure 18. Rental regulations lead to long queues
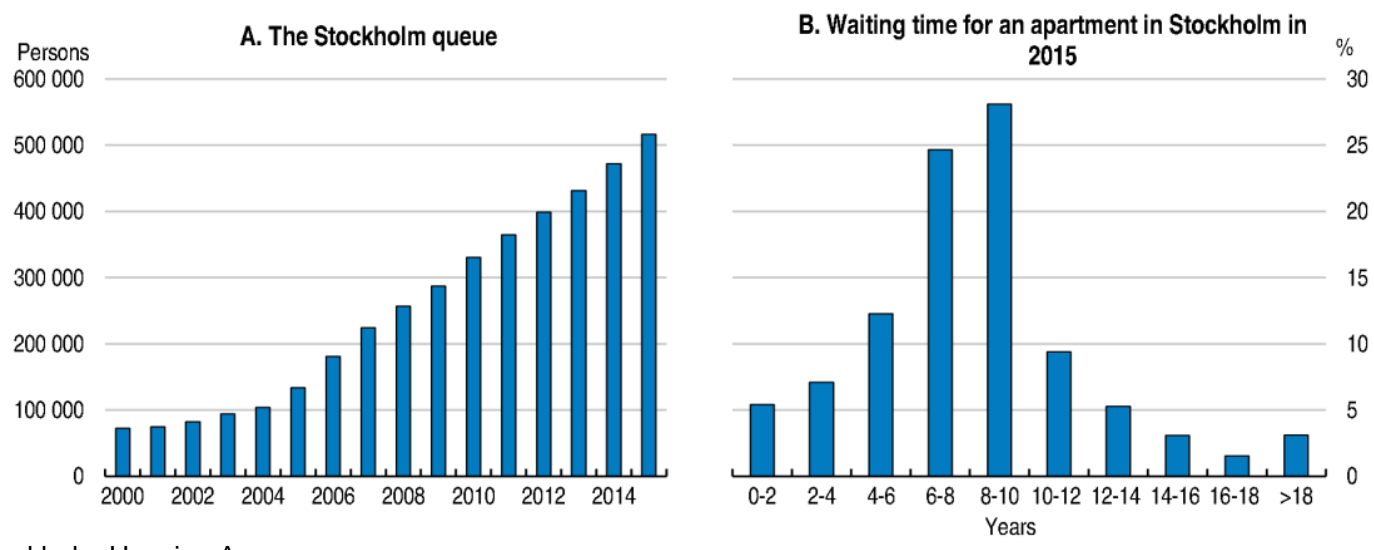

Source: Stockholm Housing Agency.

It is questionable whether current regulations increase the affordability of rental housing in general. Rental regulations reduce incentives to construct rental property and increase incentives to convert properties from rental to tenant-owned (where a tenant-owner association owns a property, in which every member has its own apartment). They also result in sub-optimal use of the current housing stock, through lock-in effects and incentives to over-consume under-priced housing services. The total effect on average Swedish rents is uncertain, but there is no clear evidence that rent controls lead to lower rents across OECD countries (Andrews et al., 2011). Andersson and Söderberg (2012) estimate that deregulation could result in welfare gains of SEK $20 \mathrm{bn}$ ( $0.5 \%$ of Swedish GDP) from a better use of the existing housing stock in inner Stockholm alone.

Rent controls may also contribute to gentrification and segregation (Lind, 2015). Following significant renovation, the rent can be set at the level of a newly built apartment of similar standard, which is close to a counterfactual market rent. Normal maintenance is widely defined and does not give the right to raise rents. Hence there are strong incentives to upgrade apartments in attractive locations to high standards and raise the rent correspondingly, while incentives for maintenance are low, which may affect the quality of a large part of the housing stock.

Segregation is higher in the rental sector than in the tenant-owned sector on most measures. Inhabitants of rent-controlled apartments in attractive locations in Stockholm are less likely to have a foreign background and more likely to have higher education, they have fewer children and they are on average older than in the tenant-owned segment of the housing market. However, the income differential between inhabitants of attractive and less attractive locations is lower in the rental market than in the tenant-owned sector, reflecting fairly similar rent levels across locations (Enström Öst et al., 2014).

The lack of rental housing has pushed some tenants towards the black market, where they are vulnerable to abuse. Foregoing a tenant right in an attractive location at a price significantly below market has a sizeable cost. This reduces mobility, but also feeds the black market, which consists of illegal trade in leases, unauthorised subletting with illegal additional rent charges and pure fraud. A lack of data makes it difficult to estimate the size of the black market precisely, but the illegal trade in leases alone was estimated at SEK 1.2bn in the Stockholm region in 2006 (Housing Crisis Committee, 2014).

Newly arrived migrants are particularly vulnerable, since in addition to limited equity, income and relevant networks, they are unfamiliar with regulatory procedures. They are more likely to end up in poorly maintained housing in less attractive locations, to pay excessive rents and to live in overcrowded accommodation (Figure 19). 
Figure 19. Non-EU migrants are likely to live in overcrowded housing

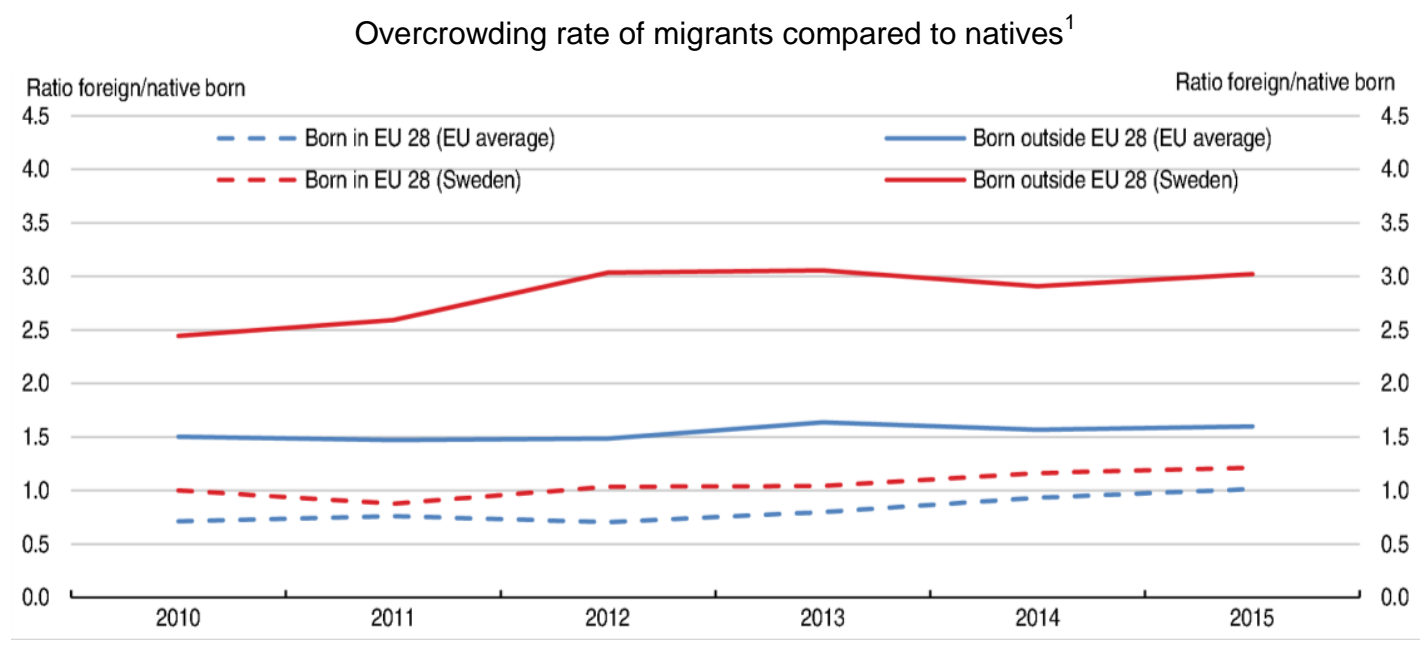

1. The overcrowding rate is defined as the percentage of the population living in an overcrowded housing unit. A person is considered as living in an overcrowded housing unit if the household does not have at its disposal a minimum number of rooms equal to: one room for the household; one room per couple in the household; one room for each single person aged 18 or more; one room per pair of single people of the same gender between 12 and 17 years of age; one room for each single person between 12 and 17 years of age and not included in the previous category; one room per pair of children under 12 years of age.

Source: Eurostat, Income and Living Conditions database.

Some predictability of rents and protection of the right of tenure increases the effectiveness of the rental market, but it is necessary to bring rents in line with supply and demand. A transition to a marketbased system should be gradual, with a cap on annual rent increases to ease the transition for those who rent an apartment in the current system. Rents in new contracts should be determined by the market. Some regulation of rents while a tenant occupies an apartment is beneficial, for example by limiting annual rent adjustments to increases in an agreed index. Mechanisms should be designed to ensure that rents do not drift too far from market level to ensure profitability for the owner and avoid lock-in effects. Access to housing for low-income households could be facilitated by some prioritisation in the allocation of municipal housing. Allocation rules could be designed to limit spatial segregation, for example by taking into account the existing social mix in specific locations.

\section{Top incomes, wealth and equal opportunity}

A substantial part of the increase in inequality over the past decades is driven by rising top incomes. The rising income share of the top $10 \%$ was to a large extent driven by the income share of the top $1 \%$, which more than doubled from 1975 to 2013 from 2.8\% in 1975 to $7.4 \%$ in 2013 after taxes and transfers (Figure 20). Until 2006, top incomes rose mainly as a result of realised capital gains, boosted by asset prices. These capital gains are concentrated among individuals with already high incomes (Roine and Waldenstrom, 2012 and 2015). Dividends have grown fast following a 2006 tax reform that increased both the scope and incentives for income shifting. In addition to affecting income inequality, wealth also matters for intergenerational income mobility. But the wealth distribution is poorly tracked in Sweden, as the collection of wealth data was abandoned in 2007. 
Figure 20. Rising top incomes contributed strongly to widening inequality ${ }^{1}$

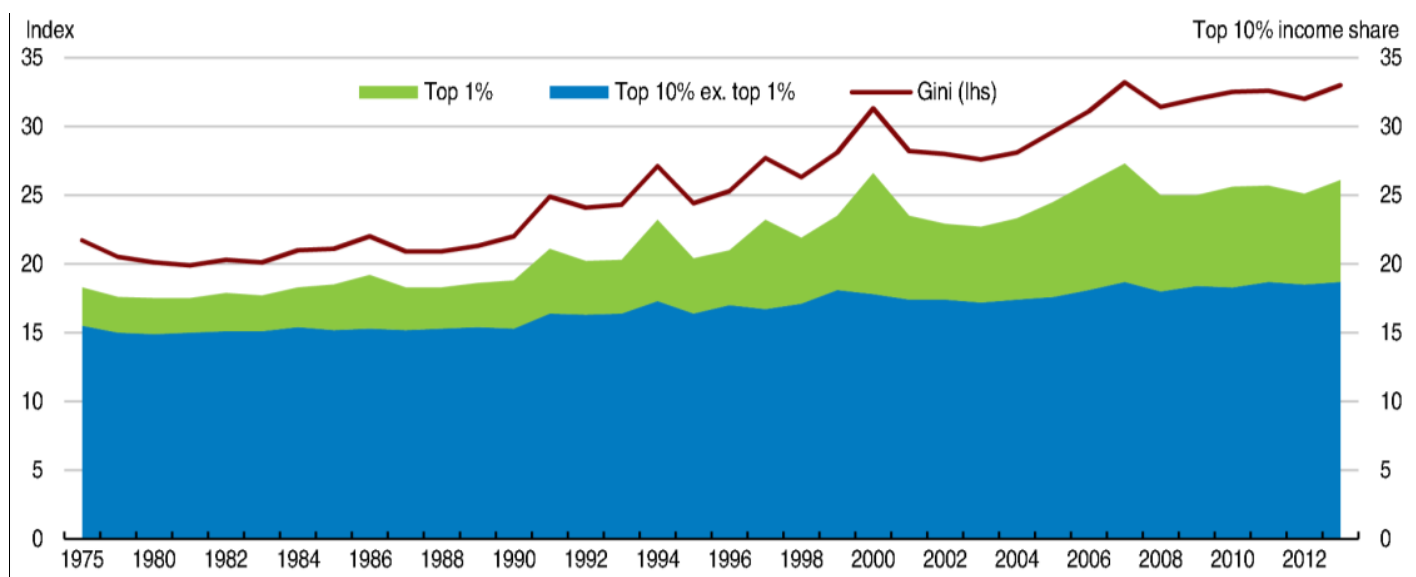

1. Household disposable income including realised capital gains.

Source: Statistics Sweden.

Income mobility is generally quite high in Sweden, and more than half of individuals leave the bottom income decile within five years (Figure 21, Panel A). Intergenerational mobility is high compared to most OECD countries, but somewhat lower than in the other Nordics (Corak, 2016; Figure 21, Panel B). Social background and circumstances, such as parental earnings and IQ, explain only around a quarter of Gini inequality, while individual efforts (and luck) determine more than $70 \%$. In the very top of the income distribution this is not the case. Fathers' relative incomes determine $90 \%$ of sons' incomes among the top $0.1 \%$, largely because of capital income. Furthermore, mobility from the bottom $75 \%$ to the top $0.1 \%$ is close to non-existent (Björklund et al., 2012a and 2012b). The low income mobility at the top end of the distribution is likely the result of inherited wealth. Analyses like this demand very detailed micro-data and internationally comparable analyses do not exist.

Figure 21. Income mobility is high in general
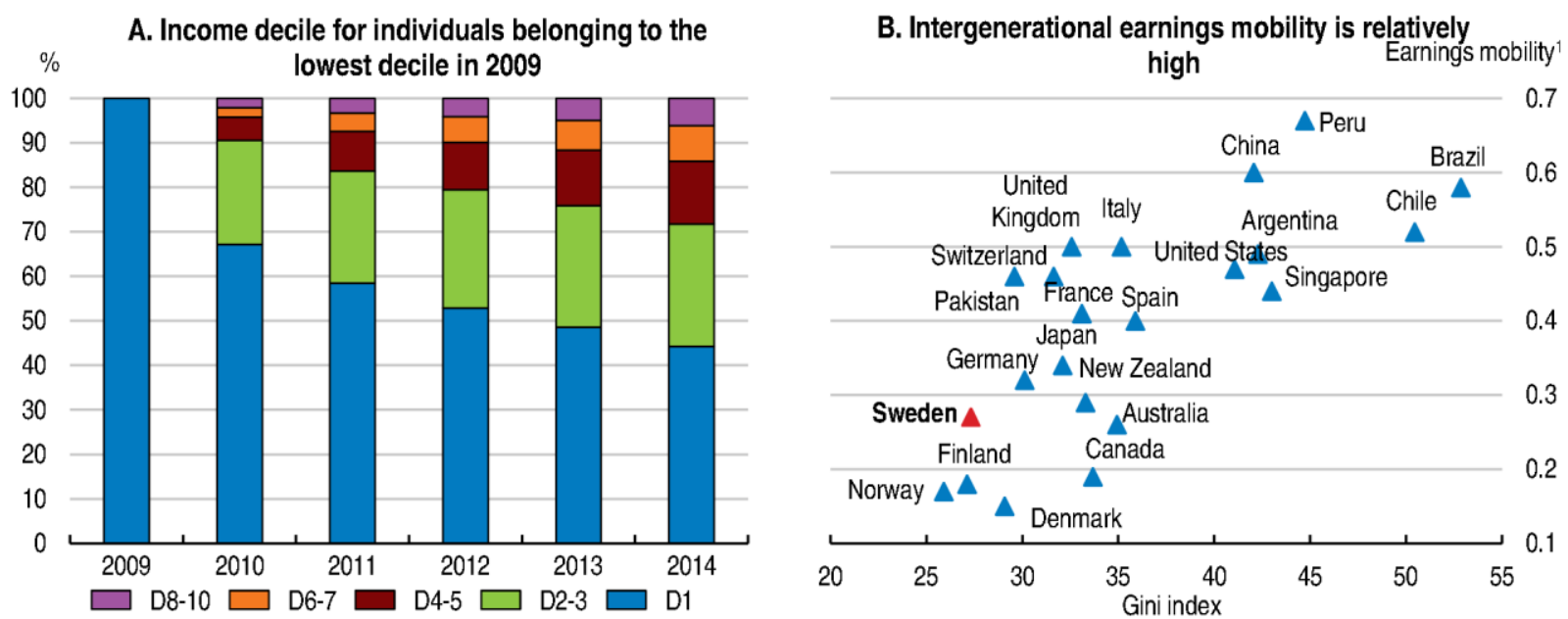

1. Father-to-son correlation of earnings relative to the income distribution.

Source: Ministry of Finance (2016a), Corak (2016).

The extent to which capital has become more concentrated in Sweden over time is uncertain. Official figures suggest that wealth concentration has only increased slightly after having bottomed out in the early 1980s, following a continuous decline from around 1910. However, capital controls were removed and financial assets surged in value after 1985. Wealth and inheritance taxes were also high at the time. These developments gave strong incentives and better opportunity to reduce taxable wealth and inheritance or move wealth abroad. Wealth held as ownership in family firms creates a further discrepancy between 


\section{ECO/WKP(2017)26}

official (taxable until 2006) private wealth and the real value of holdings. Adding also household wealth of Swedish citizens held abroad, as estimated based on financial account discrepancies, shows that the wealth share of the top $1 \%$ may plausibly have increased from $17 \%$ in 1975 to $40 \%$ in 2006, contrasting with the official estimate of 19\% (Roine and Waldenstrom, 2009).

Given that capital gains and capital income have contributed to increasing income inequality in Sweden, the decision to discontinue the collection of wealth statistics when the wealth tax was abolished in 2007 is unfortunate. However, wealth data are currently available in various registries, such as property registries and registries of financial asset holdings. Such data can be used to produce detailed wealth statistics, as has recently been done in Denmark, but no institution has the mandate to do so in Sweden. Furthermore, legal obstacles, including privacy law and the strictness of interpretation of the law by the institutions concerned also come in the way of such an undertaking. Tracking the wealth distribution facilitates analyses of inequality, and also increases the transparency of the distribution of power and influence.

\section{Box 3. Recommendations to contain the rise in inequality}

\section{Main recommendations}

Review annually the distributional consequences of uprating social benefits, taking equity, fiscal costs and work incentives into consideration.

Continue to simplify the procedures to help migrants get residence and work permits.

Rationalise by merging and harmonising various wage subsidy schemes to better target the most vulnerable workers, ease the related administrative burden and increase take-up.

Ease rental regulations to incentivise rental housing supply, mobility and better utilisation of the housing stock, while maintaining tenant protection against abuse.

Reform the recurrent property tax to better align tax charges with property values. Phase out the deductibility of mortgage interest rate payments.

\section{Further recommendations}

Consider some prioritisation of low-income households to municipal housing with allocation rules designed to limit spatial segregation.

Build on successful experiences at the local level to enhance the efficiency of integration.

Record wealth data for analytical purposes. 
ECO/WKP(2017)26

\section{REFERENCES}

Adalet McGowan, M. (2013), "Housing, financial and capital taxation policies to ensure robust growth in Sweden", OECD Economics Department Working Papers, No. 1024, OECD Publishing. http://dx.doi.org/10.1787/5k4c0vtc1kkk-en.

Adermon, A. and M. Gustavsson (2015), "Job polarization and task-biased technological change: Evidence from Sweden, 1975-2005”, The Scandinavian Journal of Economics, Vol. 117, No.3.

Aghion, P. et al. (2015), "Innovation and top income inequality", NBER Working Papers, No. 21247.

Andersen, T. and J. Maibom (2016), “The big trade-off between efficiency and equity - is it there?", Centre for Economic Policy Research, London.

Andersson Joona, P. et al. (2016), "Reforming the Integration of Refugees: The Swedish Experience", IZA Discussion Paper, No. 10307, Bonn.

Andrews, D., A. Caldera Sánchez and Å. Johansson (2011), "Housing markets and structural policies in OECD countries", OECD Economics Department Working Papers, No. 836, OECD Publishing. doi: $10.1787 / 5 \mathrm{kgk} 8 \mathrm{t} 2 \mathrm{k} 9 \mathrm{vf} 3$-en.

Andersson, R. and B. Söderberg (2012), "Elimination of rent control in the Swedish rental housing market: why and how?", Journal of Housing Research, No. 21:2.

Åberg, R. (2016), "Polariseringens fördelningseffekter" ("Distributional consequences of polarisation”), Ekonomisk debatt, No. 44:5.

Barth, E. and K. Moene (2012), "The equality multiplier - How wage setting and welfare spending make similar countries diverge", IZA Discussion Papers, No. 6494, Bonn.

Barth, E., H. Finseraas and K. Moene (2015), "Political reinforcement: how rising inequality curbs manifested welfare generosity", American Journal of Political Science, Vol. 59, No. 3. doi:10.1111/ajps.12129.

Bergh, A. (2011), "The rise, fall and revival of the Swedish welfare State: What are the policy lessons from Sweden?”, Research Institute of Industrial Economics Working Paper, No. 837, Stockholm.

Björklund, A., M. Jantti, and M. Lindquist (2009), "Family background and income during the rise of the welfare state: Brother correlations in income for Swedish men born 1932-1968", Journal of Public Economics.

Björklund, A., J. Roine and D. Waldenström (2012a), "Intergenerational top income mobility in Sweden: Capitalist dynasties in the land of equal opportunity?", Journal of Public Economics, Vol. 96, Issues 5-6. 


\section{ECO/WKP(2017)26}

Björklund, A., M. Jäntti and J. Roemer (2012b), "Equality of opportunity and the distribution of long-run income in Sweden", Social Science and Welfare, No. 39:2.

Blundell, R. and B. Etheridge (2010), "Consumption, income and earnings inequality in Britain", Review of Economic Dynamics, Vol. 13, No. 1.

Böhlmark, A., H. Holmlund and M. Lindahl, "School choice and segregation: evidence from Sweden", IFAU Working Papers, No. 2015:8.

Bussi, M. and J. Pareliussen (2015), "Skills and labour market performance in Sweden", OECD Economics Department Working Papers, No. 1233, OECD Publishing, Paris. http://dx.doi.org/10.1787/ 5 js0cqunzx9v-en.

Corak, M. (2016), "Inequality from generation to generation: The United States in comparison", IZA Discussion Papers, No. 9929, Bonn.

Cournède, B., O. Denk, P. Garda and P. Hoeller (2016), "Enhancing economic flexibility: what is in it for workers?", OECD Economic Policy Papers, forthcoming, OECD Publishing, Paris.

Domeij, D. and M. Flodén (2010), "Inequality trends in Sweden 1978-2004", Review of Economic Dynamics, Vol. 13, Issue 1.

Edling, J. (2015), Föroterna som moder Svea glömde (The suburbs mother Svea forgot), Verdandi, Stockholm.

Eliasson, T. and O. Skans (2014), "Negotiated wage increases and the labor market outcomes of low-wage workers: evidence from the Swedish public sector", IFAU Working Paper, No. 2014:10, Uppsala.

Elvander, N. (2002), "The new Swedish regime for collective bargaining and conflict resolution: a comparative perspective", European Journal of Industrial Relations, Vol. 8, No. 2. doi:10.1177/095968010282005.

Engdahl, M. (2016), "Invandringens arbetsmarknadseffekter" (Labour market effects of immigration), IFAU Report, No. 2016:10, Uppsala.

Enström Öst, C., B. Söderberg and M. Wilhelmsson (2014), "Household allocation and spatial distribution in a market under ("soft") rent control", Journal of Policy Modeling, Vol. 36, No. 2.

Eurofound (2014), Drivers of Recent Job Polarisation and Upgrading in Europe - European Jobs Monitor 2014, European Foundation for the Improvement of Living and Working Conditions, Dublin.

Eurostat (2016), Glossary: Material deprivation, website, accessed 27 July 2016, Eurostat, Luxembourg.

Fiscal Policy Council (2013), Swedish Fiscal Policy 2013 - Fiscal Policy Council Report 2013, Stockholm.

Fiscal Policy Council (2014), Swedish Fiscal Policy 2014 - Fiscal Policy Council Report 2014, Stockholm.

Fiscal Policy Council (2016), Swedish Fiscal Policy 2016 - Fiscal Policy Council Report 2016, Stockholm.

Forslund, A. et al. (2014), “Avtalslöner, löner och sysselsättning” (Wage agreements, wages and employment), IFAU Report, No. 2014:8, Uppsala. 
Fournier, J. and A. Johansson (2016a), "The effect of the public spending mix on growth and inequality", OECD Economics Department Working Paper, forthcoming.

Fournier, J. and A. Johansson (2016b), "Trends in public finance: insights from a new detailed dataset", OECD Economics Department Working Paper, forthcoming.

Goos, M., A. Manning and A. Salomons (2009), "Job polarization in Europe", American Economic Review, No. 99:2.

Gould, E. and A. Hijzen (2016), "Growing apart, losing trust? The impact of inequality on social capital", IMF Working Papers, No. 2016:176, Washington.

Gunnarsson, L., B. Korpi and U. Nordenstam (1999), Early Childhood Education and Care Policy in Sweden, Ministry of Education and Science, Stockholm.

Heathcote, J., F. Perri and G. Violante (2010), "Unequal we stand: An empirical analysis of economic inequality in the United States, 1967-2006", Review of Economic Dynamics, Vol. 13, No. 1.

Holmlund, H. et al. (2016), "Education and equality of opportunity: what have we learned from educational reforms?", IFAU Working Paper, No. 2016:5, Uppsala.

Housing Crisis Committee (2014), A Functioning Housing Market - A Reform Agenda, Stockholm.

ISF (2014), "Utvecklingen av socialförsäkringsförmåner sedan 1990-talet" (The development of social insurance benefits since the 1990s), Swedish Social Insurance Inspectorate Report, 2014:4.

Johansson, M. and T. Lindh (2006), "Inkomst och ojämlikhet i Sverige 1951-2002" (Income and inequality in Sweden 1951-2002), Institutet för Framtidsstudier; 2006:3.

Labour Market Economic Council (2016), Arbetsmarknadsekonomisk rapport - Dags för större lönespridning? (Labour Market Economic Report - Time for More Wage Dispersion?), Stockholm.

Lind, H. (2015), "The effect of rent regulations and contract structure on renovation: a theoretical analysis of the Swedish system", Housing, Theory and Society, No. 32:4.

Lindbeck, A. (1997), “The Swedish Experiment”, Journal of economic Literature, Vol. 35, No. 3.

Ministry of Employment (2016), Uppdrag om förenklade och mer effektiva processer för nyanlända (Mandate of simplified and more efficient processes for new arrivals), Stockholm.

Ministry of Finance (2015), Fördelningspolitisk redogörelse (Distribution Policy Report), Stockholm.

Ministry of Finance (2016a), Fördelningspolitisk redogörelse (Distribution Policy Report), Stockholm.

Ministry of Finance (2016b), Guidelines for Economic and Budget Policy, Stockholm.

OECD (2011), Divided We Stand: Why Inequality Keeps Rising, OECD Publishing, Paris. DOI: http://dx.doi.org/10.1787/9789264119536-en.

OECD (2013), OECD Framework for Statistics on the Distribution of Household Income, Consumption and Wealth, OECD Publishing, Paris. DOI: http://dx.doi.org/10.1787/9789264194830-en. 
OECD (2015), In It Together: Why Less Inequality Benefits All, OECD Publishing, Paris.

DOI: http://dx.doi.org/10.1787/9789264235120-en.

OECD (2015), OECD Economic Surveys: Sweden 2015, OECD Publishing, Paris.

DOI: http://dx.doi.org/10.1787/eco_surveys-swe-2015-en.

OECD (2016a), Working Together: Skills and Labour Market Integration of Immigrants and their Children in Sweden, OECD Publishing, Paris. DOI: http://dx.doi.org/10.1787/9789264257382-en.

OECD (2016b), OECD Employment Outlook 2016, OECD Publishing, Paris. DOI: http://dx.doi.org/10.1787/empl_outlook-2016-en.

Pareliussen, J. (2017), "How self-sorting affects migrants' labour market outcomes", OECD Economics Department Working Papers, forthcoming, OECD Publishing.

Robling, P. (2015), “Immigration and Income Inequality in Sweden 1980 to 2011”, in Robling, P., Essays on the Origins of Human Capital, Crime and Income Inequality, Faculty of Social Sciences, Department of Economics, Stockholm University.

Robling, P. and J. Pareliussen (2017), "Structural inequality - The case of Sweden", OECD Economics Department Working Papers, forthcoming, OECD Publishing.

Roine, J. and D. Waldenström (2009), "Wealth concentration over the path of development: Sweden, 1873-2006", Scandinavian Journal of Economics, No. 111:1.

Roine, J. and D. Waldenström (2012), “On the role of capital gains in Swedish income inequality”, Review of Income and Wealth, 58(3).

Roine, J. and D. Waldenström (2015), "Long-Run Trends in the Distribution of Income and Wealth", Chapter in Atkinson, A.B. and F. Bourguignon (eds.), Handbook of Income Distribution, vol. 2A, North-Holland, Amsterdam, 2015.

SNAE (2016), PISA 2015, 15-åringars kunskaper i naturvetenskap, läsförståelse och matematik (PISA 2015, 15-year-olds knowledge of science, reading and mathematics), Report No. 450, Swedish National Agency for Education.

Statistics Sweden (2016), Inkomstrapport 2014 - individer och hushåll (Income report 2014 - individuals and households), Stockholm.

Social Insurance Agency (2016), En väg in - rapport från pilotprojektet Mötesplatser och information (A way In - Report from the Pilot Project Meeting Points and Information), Stockholm.

Soltow, L. (1989), "The rich and the destitute in Sweden, 1805-1855: a test of Tocqueville's inequality hypotheses", The Economic History Review, No. 42:1.

Sutherland, H. et al. (2008), “The impact of benefit and tax uprating on incomes and poverty”, Joseph Rowntree Foundation, York.

Waldenström, D. (2012), "Regeringen och ojämlikheten: en granskning av budgetens fördelningspolitiska redogörelser 1992-2011", (The Government and inequalities: A study of distribution policy aspects of the Budget), Studies in Fiscal Policy, No. 2012:6, Fiscal Policy Council. 